Article

\title{
Synthesis of Computationally Designed 2,5(6)-Benzimidazole Derivatives via Pd-Catalyzed Reactions for Potential E. coli DNA Gyrase B Inhibition
}

\author{
Rafael T. Aroso ${ }^{1}$, Rita C. Guedes ${ }^{2, *(D)}$ and Mariette M. Pereira 1,*(D) \\ 1 Coimbra Chemistry Centre, Department of Chemistry, University of Coimbra, Rua Larga, \\ 3004-535 Coimbra, Portugal; rafael.aroso@student.uc.pt \\ 2 Faculty of Pharmacy, Research Institute for Medicines (iMed.ULisboa), University of Lisbon, \\ Av. Prof. Gama Pinto, 1649-003 Lisbon, Portugal \\ * Correspondence: rguedes@ff.ulisboa.pt (R.C.G.); mmpereira@qui.uc.pt (M.M.P.)
}

Citation: Aroso, R.T.; Guedes, R.C.;

Pereira, M.M. Synthesis of

Computationally Designed

2,5(6)-Benzimidazole Derivatives via Pd-Catalyzed Reactions for Potential E. coli DNA Gyrase B Inhibition.

Molecules 2021, 26, 1326. https://

doi.org/10.3390/molecules26051326

Academic Editor: Fernanda Borges

Received: 3 February 2021

Accepted: 25 February 2021

Published: 2 March 2021

Publisher's Note: MDPI stays neutral with regard to jurisdictional claims in published maps and institutional affiliations.

Copyright: (C) 2021 by the authors. Licensee MDPI, Basel, Switzerland. This article is an open access article distributed under the terms and conditions of the Creative Commons Attribution (CC BY) license (https:/ / creativecommons.org/licenses/by/ $4.0 /)$.

\begin{abstract}
A pharmacophore model for inhibitors of Escherichia coli's DNA Gyrase B was developed, using computer-aided drug design. Subsequently, docking studies showed that 2,5(6)substituted benzimidazole derivatives are promising molecules, as they possess key hydrogen bond donor/acceptor groups for an efficient interaction with this bacterial target. Furthermore, 5(6)-bromo-2-(2-nitrophenyl)-1H-benzimidazole, selected as a core molecule, was prepared on a multi-gram scale through condensation of 4-bromo-1,2-diaminobenzene with 2-nitrobenzaldehyde using a sustainable approach. The challenging functionalization of the 5(6)-position was carried out via palladium-catalyzed Suzuki-Miyaura and Buchwald-Hartwig amination cross-coupling reactions between $\mathrm{N}$-protected-5-bromo-2-nitrophenyl-benzimidazole and aryl boronic acids or sulfonylanilines, with yields up to $81 \%$. The final designed molecules (2-(aminophen-2-yl)-5(6)-substituted- $1 H$ benzimidazoles), which encompass the appropriate functional groups in the 5(6)-position according to the pharmacophore model, were obtained in yields up to $91 \%$ after acid-mediated N-boc deprotection followed by Pd-catalyzed hydrogenation. These groups are predicted to favor interactions with DNA gyrase B residues Asn46, Asp73, and Asp173, aiming to promote an inhibitory effect.
\end{abstract}

Keywords: computational chemistry; E. coli DNA Gyrase B; benzimidazole; cross-coupling; organic catalysis

\section{Introduction}

Imidazole-based heterocycles are a common motif found in both natural and synthetic compounds, present in several clinically approved drugs [1-3]. In particular, the benzimidazole moiety is a relevant scaffold for multiple applications in clinic, showing antiulcer, antihypertensive, antiparasitic, anticancer, antifungal, and antibacterial activities [4,5]. For instance, ridinilazole, a recently developed antibacterial containing the benzimidazole scaffold, is currently in phase III clinical trials and has shown great promise for treating Clostridioides difficile infections [6].

Indeed, due to extensive and widespread bacterial resistance to current therapeutics [7] there is an urgent need to develop more efficient synthetic processes to obtain potential new antibiotics derived from a computer-aided rational design. Aiming for the development of inhibitors for the bacterial target Escherichia coli's DNA Gyrase B [3,8-10], we have used a pharmacophore model created in the Molecular Operating Environment (MOE) molecular design software (Chemical Computing Group) [11] to provide insights into the ideal structure of potential antibacterial molecules. Following the analysis of the computational pharmacophore model herein described, we have planned the synthesis of families of potential antibacterial molecules derived from the $1 \mathrm{H}$-benzimidazole scaffold (Figure 1). This core was selected as a starting point for our studies, owing to its recently reported antibacterial activity [6] and its synthetic amenability [12]. 


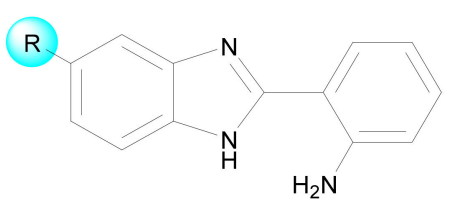

Figure 1. General structure of 2-(2-aminophenyl)-5(6)-substituted-1H-benzimidazole molecules holding the key structural functional groups, proposed by the developed pharmacophore model.

We hypothesized that the synthesis of 5(6)-halogenated-2-substituted benzimidazole by classic methods [13-15] involving a condensation reaction of a halogenated orthophenylenediamine with 2-nitrocarbonyl/carboxylphenyl would allow the preparation of a core synthon for further derivatization to match the features predicted by the pharmacophoric model.

The limitations imposed by classic multi-step methods [16,17] on the functionalization of 5(6) position of benzimidazoles have driven our efforts towards the use of palladiumcatalyzed coupling reactions, namely Suzuki-Miyaura and Buchwald-Hartwig. Current literature on this topic shows multiple reports of palladium-catalyzed reactions involving the oxidative addition to activated 2-halogen substituted benzimidazoles [18-26], or 2-aminobenzimidazoles [27], however there are only a few examples describing their application for functionalization of the less reactive 5(6) position. These examples include Suzuki-Miyaura reactions [28,29] using vinyltrifluoroboronates or benzyltrifluoroborates as coupling agents, which, in general, do not include an appropriate hydrogen-bond acceptor according to our model, and/or require multi-step processes for their preparation. There are also a few examples regarding the catalytic amination at the 5(6) position [30-34], but some challenges remain to be overcome, particularly the enhancement of the low reaction yields, and/or the need for huge amounts of expensive catalysts. In this paper, we first describe the computer-aided design of 5(6)-substituted-2-(2-aminophenyl)benzimidazole derivatives aiming at the development of potential E. coli GyrB inhibitors. In addition, we report optimized synthetic processes for preparing these newly designed benzimidazole families, which encompass the appropriate substituents, via catalytic modulation of the less explored 5(6)-positions, using benchmark palladium-catalyzed reactions, namely Suzuki-Miyaura and Buchwald-Hartwig couplings with good yields.

\section{Results and Discussion}

\subsection{Computer-Aided Design of Benzimidazole Derivatives with Potential E. coli DNA GyrB Inhibitory Activity}

To generate the pharmacophore model, an alignment of the 18 training set molecules (see Supplementary Materials: Figure S2) through a stochastic conformer search was performed in MOE (Chemical Computing Group) [11] (Figure 2A).

The common structural features were identified, from which several pharmacophore queries were generated and further refined (by varying feature types, number of features and their radius). The selection and validation of the final pharmacophore model were grounded on its performance against a dataset (test set) composed of 90 compounds $[9,10,35-41]$ whose activity is well-known (61 active and 30 inactive compounds) (see Supplementary Materials: Figure S3). The best pharmacophore query was generated using MOE's Unified scheme, and contains five features: (i) a hydrogen bond acceptor region; (ii) an aromatic or hydrophobic region; (iii) one hydrophobic region; and (iv) two hydrogen-bond donor regions. This model (Figure 2B) accurately predicted 90\% of the active compounds (from the test set), with only 5\% false positives. Figure $2 \mathrm{~B}$ shows the optimized pharmacophore model superimposed with the selected benzimidazole scaffold bearing an $-\mathrm{NH}_{2}$ (hydrogen bond donor) at 2-position and either (methylsulfonyl)phenyl, (methoxycarbonyl)phenyl and methoxyphenyl (hydrogen bond acceptors) at 5(6)-positions. 

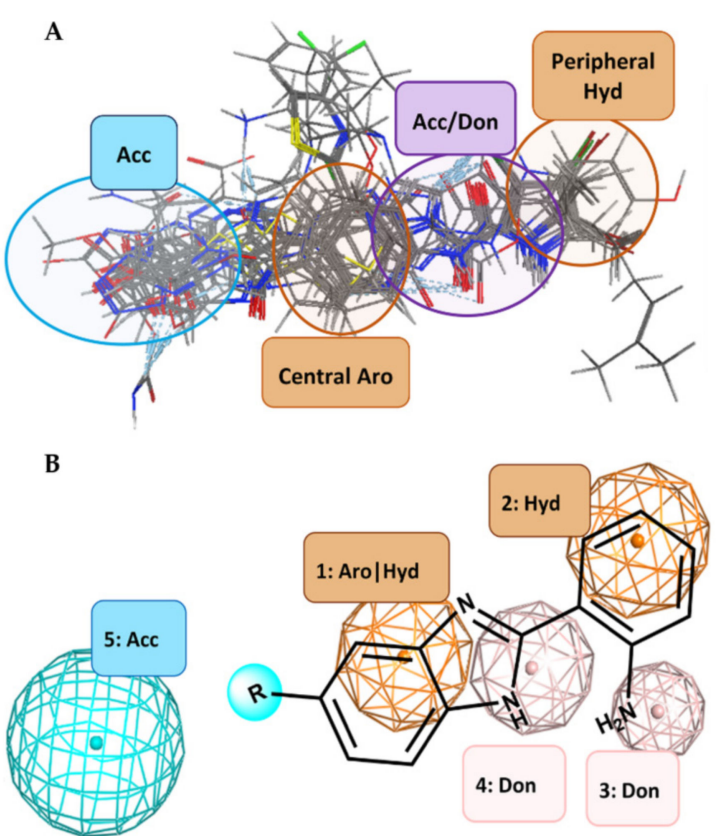

Figure 2. (A) Structural alignment of the 18 ligands from the training set and visual identification of common structural features. (B) Superimposition of the 2-(2-aminophenyl)-5(6)-substitutedbenzimidazole scaffold with the selected pharmacophore model. Acc-Hydrogen bond acceptor; AroAromatic; Don-Hydrogen bond donor; Hyd-Hydrophobic. R = (methylsulfonyl)phenyl, (methoxycarbonyl)phenyl and methoxyphenyl.

Our next goal was to determine which type of functional groups are best suited to introduce in the 5(6)- position of the benzimidazole ring. To achieve this goal, we generated a virtual library of 2-(2-aminophenyl)-5(6)-substituted-benzimidazole derivatives (in total, 6681 compounds), using MOE tools. Initially, we screened the virtual library using the pharmacophore model, which we had previously selected and validated, in order to remove those derivatives whose features did not have hydrogen-bond acceptors. Next, docking studies were performed, using E. coli's DNA GyrB ATPase binding site (PDB entry 4KFG) [42], in order to identify the derivatives with the most potential for effective inhibition of this enzyme. Briefly, using GOLD (Cambridge Crystallographic Data Centre) [43] and the ChemScore scoring function, we ranked the compounds with the highest potential. ChemScore is a fitness (or scoring) function implemented in GOLD software to estimate the receptor-ligand binding affinity. This scoring function includes several terms, namely, a protein-ligand atom clash term and an internal energy term, taking account of hydrophobic-hydrophobic contact area, hydrogen bonding, ligand flexibility, and metal interaction. Then, we compared the results to a correlation established between ChemScore values and biological activies of known inhibitors (see Supplementary Materials: Figure S3). Based on this, we selected some of the highest ranking compounds based on their synthetic feasibility (Table 1). 
Table 1. Selected 2-(2-aminophenyl)-5(6)-substituted-benzimidazole derivatives with corresponding ChemScore and predicted $\log \mathrm{IC}_{50}$ activity.

\begin{tabular}{llll}
\hline$\#$ & ChemScore & Predicted log IC 50 (nM) \\
\hline 3 & & 23.7 & 2.7 \\
\hline
\end{tabular}

As an example, Figure 3 shows the docking pose obtained for the highest scoring compound 15 (Table 1, entry 1).

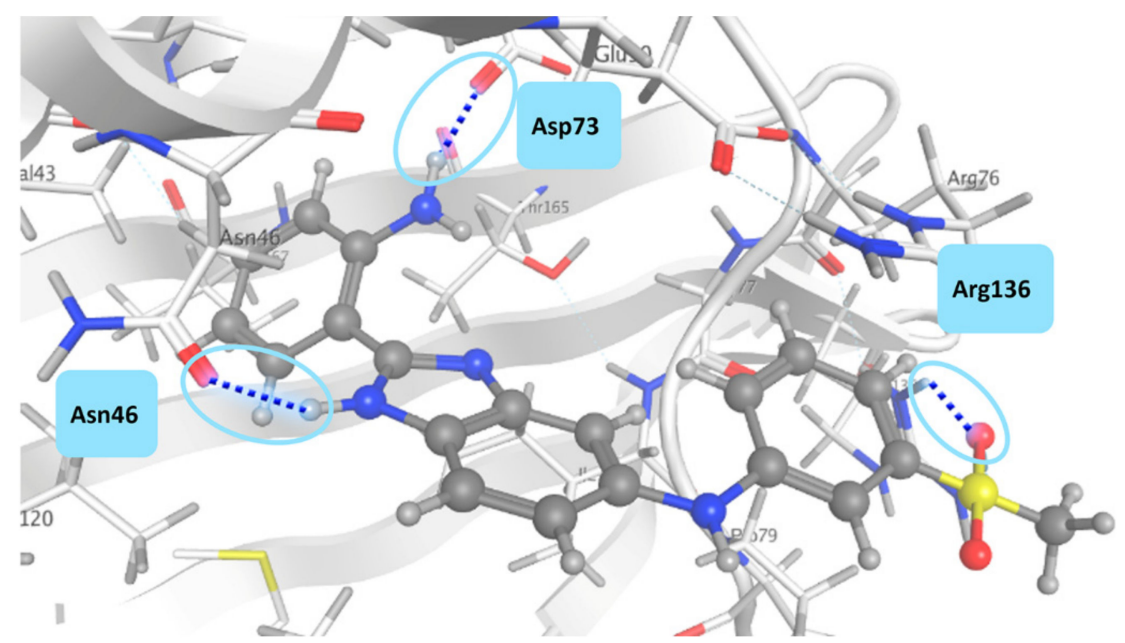

Figure 3. Docking binding mode of compound 15, as predicted by GOLD using the ChemScore function, in the ATP binding site of E. coli DNA gyrase B (PDB entry 4KFG). The protein is represented in white, with the exception of the relevant neighboring side-chains, which, along with the ligand, are color-coded according to atom type: Blue $=\mathrm{N}$; Red $=\mathrm{O}$, Yellow $=\mathrm{S}$; Dark Grey $=\mathrm{C}$; Light Grey $=\mathrm{H}$. Hydrogen bonds are indicated by blue dotted lines, and relevant protein residues are highlighted.

From the analysis of the best scoring docking poses, we can observe three relevant hydrogen bond interactions: two between the - NH groups and Asn46 and Asp73; and another between the $\mathrm{S}=\mathrm{O}$ group and $\mathrm{Arg} 136$. In addition, there are hydrophobic interactions between the aminophenyl ring and the surrounding non-polar protein side-chains. This corroborates the information obtained by the pharmacophore model as it states the importance of having hydrogen bond donors and acceptors in specific portions of the molecule, as well as aromatic/hydrophobic portions.

In sum, our aim to synthesize new families of 2-(2-aminophenyl)-5(6)-substitutedbenzimidazoles is explained by the need to insert hydrogen bond donor groups at 2 position, while modulation of the 5(6)-position will allow the insertion of hydrogen bond 
acceptor groups. These groups will favor interactions with Asp73 and Arg136, respectively, and therefore increase their inhibition potential for E. coli's DNA gyrase B.

\subsection{Synthetic Methods for the Preparation of 2-Aminophenyl-5(6)-Substituted Benzimidazole Derivatives}

A simple synthetic pathway was developed for modulation of the desired 5(6)-position of the benzimidazole ring, starting with a set of reagents with an embedded functional group that could then be transformed to yield chemically diverse derivatives. Therefore, aiming toward the preparation of benzimidazoles [44] we started with 4-bromo-1,2diaminobenzene and 2-nitrobenzaldehyde (Scheme 1).

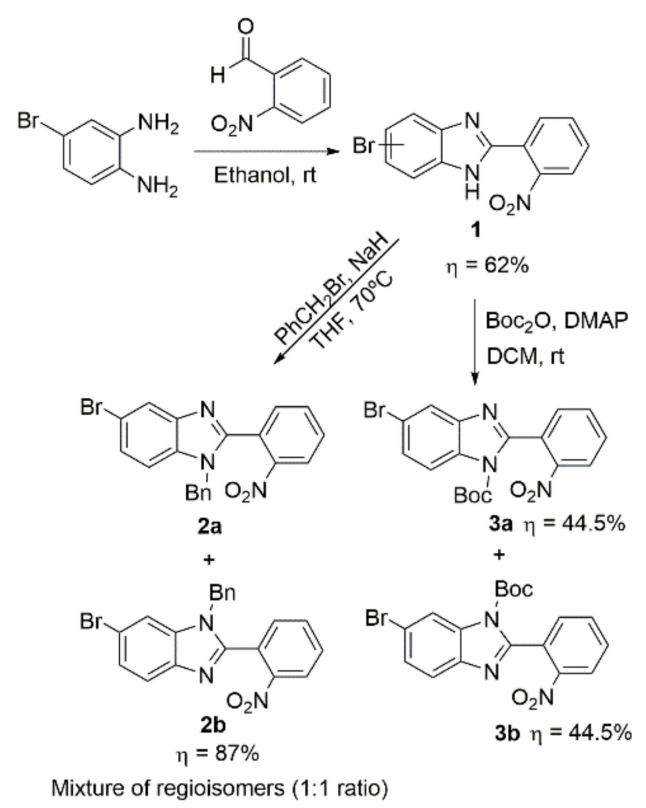

Scheme 1. Synthesis of the core 5(6)-bromo-2-(2-nitrophenyl)-1H-benzimidazole substrate.

The optimization of reaction conditions was performed for the synthesis of the nitro derivative 1. The conditions explored and the results obtained are depicted in Table 2. Firstly, the reaction was carried out by mixing approximately equimolar quantities of 4-bromo-1,2-diaminobenzene and 2-nitrobenzaldehyde, using nitrobenzene both as solvent and oxidant, and the temperature was maintained at $180^{\circ} \mathrm{C}$ for $8 \mathrm{~h}$ (Table 2, entry 1).

Since the product could not be isolated by precipitation from the reaction mixture, the nitrobenzene was distilled at reduced pressure. The product was then purified by column chromatography, using silica gel as stationary phase, and a mixture of dichloromethane/ethyl acetate as eluent. Under these conditions, product 1 was obtained at $48 \%$ isolated yield. ${ }^{13} \mathrm{C}$ and ${ }^{1} \mathrm{H}$ nuclear magnetic resonance showed broad signals (118.1, $116.5,114.7 \mathrm{ppm}$ ), typical of tautomerism associated with this class of compounds (see Supplementary Materials: Figures S5 and S6). Then, in order to avoid this troublesome distillation step, nitrobenzene was replaced by ethanol and the reaction was carried out both at reflux temperature $\left(80^{\circ} \mathrm{C}\right)$ and room temperature $\left(25^{\circ} \mathrm{C}\right)$ in air atmosphere, over $3 \mathrm{~h}$ (Table 2, entry 2-3). This methodology gave similar yields for product $1(47-50 \%)$, but a significantly easier work-up. Indeed, oxidation/aromatization could proceed using the atmospheric oxygen [45], without the need of using nitrobenzene, usually described as the oxidant $[44,46]$. To improve the yield via activation of carbonyl group, we evaluated the effect of Montmorillonite K10 as a heterogeneous acid reusable catalyst, and both the reproducibility of the reaction and the final isolated yield increased to $62 \%$ when the reaction was performed at $25{ }^{\circ} \mathrm{C}$ (Table 2, entries 4). Using this synthetic methodology, compound 1 was obtained at a multi-gram scale $(2.64 \mathrm{~g}, 8.3 \mathrm{mmol})$ and was then used as a starting material for further modifying the 5(6)-position of the benzimidazole ring. 
Before starting the functionalization through Pd-catalyzed reactions, we proceeded with the benzimidazole $-\mathrm{NH}$ protection using benzyl or boc as protecting groups. In short, to a solution of the starting material $\mathbf{1}$, in dry tetrahydrofuran (THF) at $0{ }^{\circ} \mathrm{C}$ and under inert atmosphere, $\mathrm{NaH}$ was added, followed by benzyl bromide and a catalytic amount of tetra- $n$-butylammonium iodide (TBAI). The reaction was then heated to $70^{\circ} \mathrm{C}$ for $2 \mathrm{~h}$. After conventional work-up procedures, product $\mathbf{2}(\mathbf{2} \mathbf{a}+\mathbf{2} \mathbf{b})$ was isolated as a mixture of two regioisomers with $87 \%$ yield. As can be seen from the ${ }^{1} \mathrm{H}$ NMR spectra (see Supplementary Materials: Figure S11), the isomers were formed in a 1:1 ratio, and were used as such in further reactions.

Table 2. Optimization of the reaction conditions for the condensation reaction between 4-bromo-1,2diaminobenzene and 2-nitrobenzaldehyde ${ }^{(a)}$.

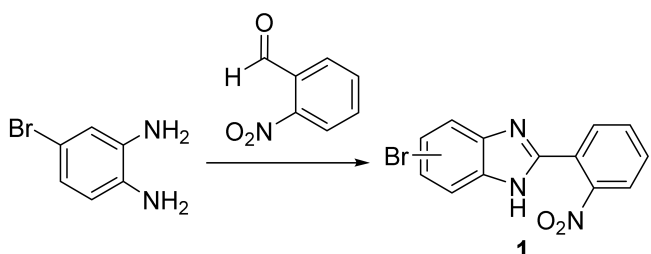

\begin{tabular}{cccccc}
\hline$\#$ & T $\left({ }^{\circ} \mathbf{C}\right)$ & Time $(\mathbf{h})$ & Solvent & Catalyst & Isolated Yield-1 (\%) \\
\hline 1 & 180 & 8 & Nitrobenzene & - & 48 \\
\hline 2 & 80 & 3 & Ethanol & - & 47 \\
\hline 3 & 25 & 6 & Ethanol & - & 50 \\
\hline 4 & 25 & 4 & Ethanol & Montmorillonite K10 & 62 \\
\hline 5 & 80 & 2 & Ethanol & Montmorillonite K10 & 54 \\
\hline
\end{tabular}

(a) Typical reaction conditions: 4-bromo-1,2-diaminobenzene (1.1 mmol), 2-nitrobenzaldehyde (1.2 mmol) and the catalyst $(20 \mathrm{mg})$ were mixed in the solvent $(3 \mathrm{~mL})$ and heated to the designated temperature, over a variable time period.

We proceeded with Pd-catalyzed reactions, using the mixture of $N$-benzyl-benzimidazole isomers, $\mathbf{2}$, as substrate. Scheme 2 shows all the optimized reaction conditions and corresponding yields.

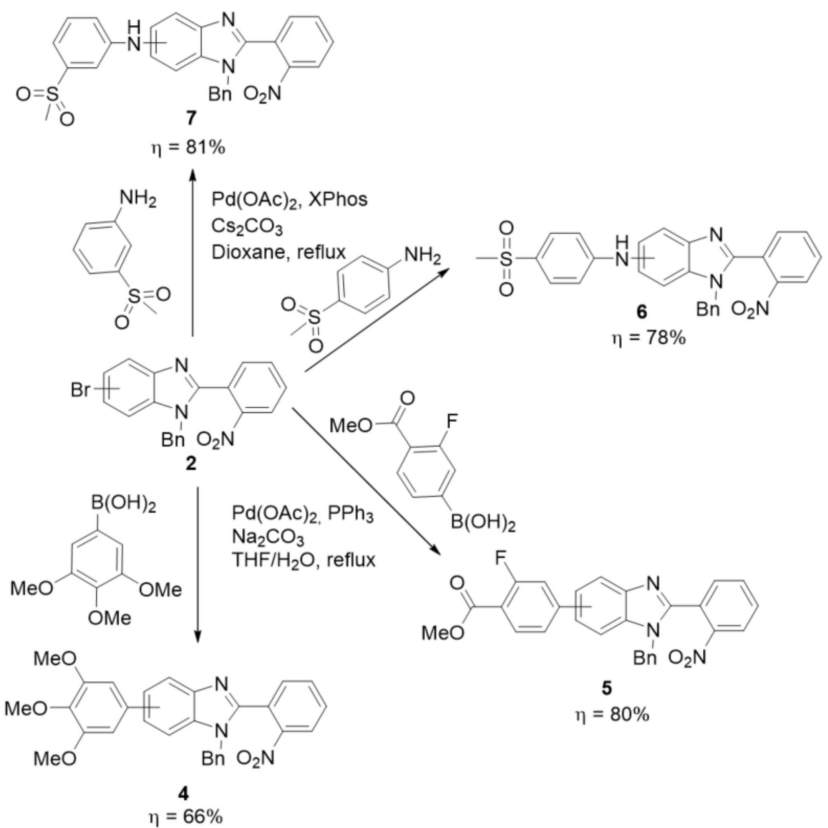

Scheme 2. Pd-catalyzed reactions involving the $N$-benzyl-protected benzimidazole (2). 
First, based on the computational model (mentioned above), we choose two boronic acids with hydrogen-bond acceptors present in different functional groups: (i) ether $(3,4,5-$ trimethoxyphenylboronic acid); and (ii) ester and fluorine (3-fluoro-4-(methoxycarbonyl) phenylboronic acid).

In the first approach, through a Suzuki-Miyaura Pd-coupling reaction [47-49], the substrate 2 and the selected boronic acid were dissolved in a mixture of $\mathrm{DME} / \mathrm{EtOH}$ 1:1, and the solvent was degassed. Then, $\mathrm{Pd}(\mathrm{OAc})_{2}$ and $\mathrm{PPh}_{3}$ were added and, after an incubation time of $15 \mathrm{~min}$ at room temperature, an aqueous solution of $\mathrm{K}_{2} \mathrm{CO}_{3}$ was added, after which the reaction was heated and maintained at $90{ }^{\circ} \mathrm{C}$ for $72 \mathrm{~h}$. After the usual work-up procedure followed by purification by column silica gel chromatography, the compound 4 was isolated, as a mixture of isomers, in $30 \%$ yield. Aiming to improve the yield of this reaction, the solvent was changed to a mixture of $\mathrm{THF} / \mathrm{H}_{2} \mathrm{O}$ (4:1). After being degassed, $\mathrm{Pd}(\mathrm{OAc})_{2}, \mathrm{Ph}_{3} \mathrm{P}$, and $\mathrm{K}_{2} \mathrm{CO}_{3}$ were added, and the reaction was carried out at $70{ }^{\circ} \mathrm{C}$ for only $16 \mathrm{~h}$. After a simple work-up, 4 was isolated in $66 \%$ yield. By applying these optimized reaction conditions, the formation of ester hydrolysis products was not observed and 5 was isolated in $80 \%$ yield.

Then, to prepare a family of molecules containing the sulfonylaniline group at 5(6)benzimidazol position (the best scoring family according to the model: Table 1, entry 1), the optimization of Pd-catalyzed Buchwald-Hartwig amination [50] reaction was carried out and the results are presented in Table 3.

Table 3. Optimization of the reaction conditions for the Buchwald-Hartwig coupling of benzyl protected benzimidazole 2 with 4-(methylsulfonyl)aniline ${ }^{(a)}$.

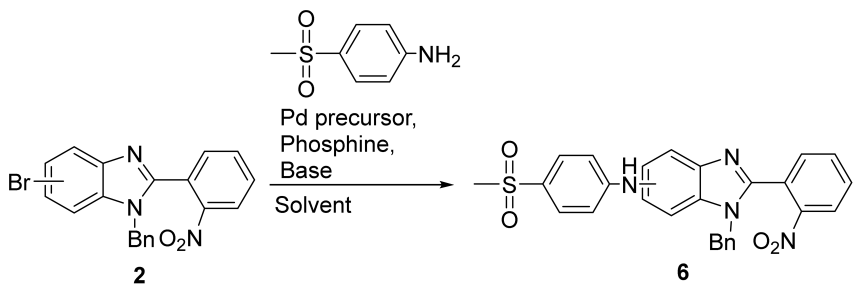

\begin{tabular}{cclcc}
\hline$\#$ & Phosphine & Solvent & Sub/Cat & Conv (\%) \\
\hline 1 & $15 \mathrm{~mol} \%$ BINAP & Toluene & 10 & trace \\
\hline 2 & $15 \mathrm{~mol} \%$ DPEphos & Toluene & 10 & trace \\
\hline 3 & $15 \mathrm{~mol} \%$ XPhos & Toluene & 10 & 91 \\
\hline 4 & $15 \mathrm{~mol} \%$ BINAP & Dioxane & 10 & trace \\
\hline 5 & $15 \mathrm{~mol} \%$ DPEphos & Dioxane & 10 & trace \\
\hline 6 & $15 \mathrm{~mol} \%$ XPhos & Dioxane & 10 & $100(78)^{\mathrm{b})}$ \\
\hline $7^{\mathrm{c})}$ & $15 \mathrm{~mol} \%$ XPhos & Dioxane & 10 & 79 \\
\hline 8 & $7.5 \mathrm{~mol} \%$ XPhos & Dioxane & 20 & 57
\end{tabular}

BINAP:(2,2'-bis(diphenylphosphino)-1,1'-binaphthyl); DPEphos: bis[(2-diphenylphosphino)phenyl] ether; Xphos: [2-Dicyclohexylphosphino-2', $4^{\prime}, 6^{\prime}$-triisopropylbiphenyl]. (a) Typical reaction conditions: 2 (0.74 mmol); 4(methylsulfonyl)aniline (0.88 mmol); $\mathrm{Cs}_{2} \mathrm{CO}_{3}(1.47 \mathrm{mmol}) ; \mathrm{Pd}(\mathrm{OAc})_{2}(0.074 \mathrm{mmol}) ;$ phosphine $(0.11 \mathrm{mmol})$; solvent $(5 \mathrm{~mL})$; Temperature $=100{ }^{\circ} \mathrm{C}$; Time $=16 \mathrm{~h} ;(\mathbf{b})$ Isolated yield; $(\mathbf{c})$ Time $=8 \mathrm{~h}$.

In a typical experiment, substrate 2 was mixed with 4 -(methylsulfonyl)aniline, using $\mathrm{Cs}_{2} \mathrm{CO}_{3}$ as base and $\mathrm{Pd}(\mathrm{OAc})_{2} /$ phosphine, and the reaction was carried out at $100{ }^{\circ} \mathrm{C}$ for $16 \mathrm{~h}$. First, the reaction was performed in toluene, using Pd/BINAP, Pd/DPEphos, and $\mathrm{Pd} / \mathrm{XPhos}$ and a remarkable effect of the phosphine structure was observed (Table 3 , entries 1-3). The reaction could only be carried out in the presence of palladium/XPhos, yielding 91\% conversion after $16 \mathrm{~h}$ (Table 3, entry 3). To improve the solubility of the reaction components and evaluate the solvent effect, toluene was then replaced by dioxane and the reaction was performed under the same conditions. Again, BINAP and DPEphos 
did not originate an active catalytic system (Table 3, entry 4-5), the palladium/XPhos being slightly more active in this solvent (100\% conversion, Table 3 , entry 6$)$. Then, we reduced the reaction time from $16 \mathrm{~h}$ to $8 \mathrm{~h}$, and 79\% conversion was obtained (Table 3, entry 7). Finally, we increased the substrate/catalyst ratio from 10 to 20 and, after 16 h, only $57 \%$ substrate conversion was obtained (Table 3, entry 8). Overall, these results show that the catalytic activity is strongly dependent of the structure of palladium/phosphine catalyst, with the sterically hindered monodentate phosphine XPhos providing the most active catalytic system under these conditions, as previously reported [51].

Under our optimized conditions (Table 3, entry 6), and upon work-up procedure and purification by column chromatography in silica gel, the products $\mathbf{6}$ and $\mathbf{7}$ were isolated in yields of $78 \%$ and $81 \%$, respectively (Scheme 2). Do, despite the lower nucleophilicity of the para derivative, when compared with the meta analogue, this factor did not translate into a noteworthy difference in reaction yield under the described conditions. To obtain the initially designed structures (Table 1 ), deprotection of the benzyl group was performed via catalytic hydrogenation using $\mathrm{H}_{2}$ and $\mathrm{Pd} / \mathrm{C}$ [52], under mild conditions $\left(50{ }^{\circ} \mathrm{C}, 3 \mathrm{bar}\right.$ $\mathrm{H}_{2}$ ) for $8 \mathrm{~h}$. Nevertheless, after this time no benzyl deprotection occurred, and only the reduction of $-\mathrm{NO}_{2}$ was observed. Therefore, we used more vigorous reaction conditions $\left(80{ }^{\circ} \mathrm{C}, 5\right.$ bar $\left.\mathrm{H}_{2}\right)$, but a complex mixture of products was obtained.

To overcome this synthetic challenge, we decided to protect the benzimidazole 1 with boc, yielding $\mathbf{3 a}$ and $\mathbf{3} \mathbf{b}$ (Scheme 1). The reaction was carried out in dichloromethane (DCM) for $24 \mathrm{~h}$, at room temperature, with the addition of tert-butyldicarbonate and 4dimethylaminopyridine (DMAP) as base. Following standard work-up, products $3 \mathbf{a}$ and $3 \mathbf{b}$ were obtained at $44.5 \%$ yield each ( $89 \%$ combined yield). It should be noted that, in this case, both isomers $\mathbf{3 a}$ and $\mathbf{3 b}$ could be easily separated by silica chromatography, being isolated and fully characterized. The assignment of each regioisomer was done using 2D-NOESY (see Supplementary Materials: Figures S18 and S23). Then, using the reaction conditions described above, $\mathbf{3 a}$ or $\mathbf{3} \mathbf{b}$ were coupled with 3,4,5-trimethoxyphenyl boronic acid or 3-fluoro-4-(methoxycarbonyl)phenyl boronic acid, giving products $8 \mathbf{a}$ or $\mathbf{8 b}$ and $\mathbf{9 a}$ or $9 \mathbf{b}$ with approximately the same NMR yields ( $75 \%$ and $70 \%$, respectively). This result points to the fact that both regioisomers have similar reactivity towards Suzuki-Miyaura coupling. For further studies, isolation and full characterization, only the products $\mathbf{8 a}$ and $9 \mathbf{a}$ have been isolated upon column chromatography, in $72 \%$ and $66 \%$ isolated yields, respectively (Scheme 3). Full characterization is presented in the experimental section and SI.

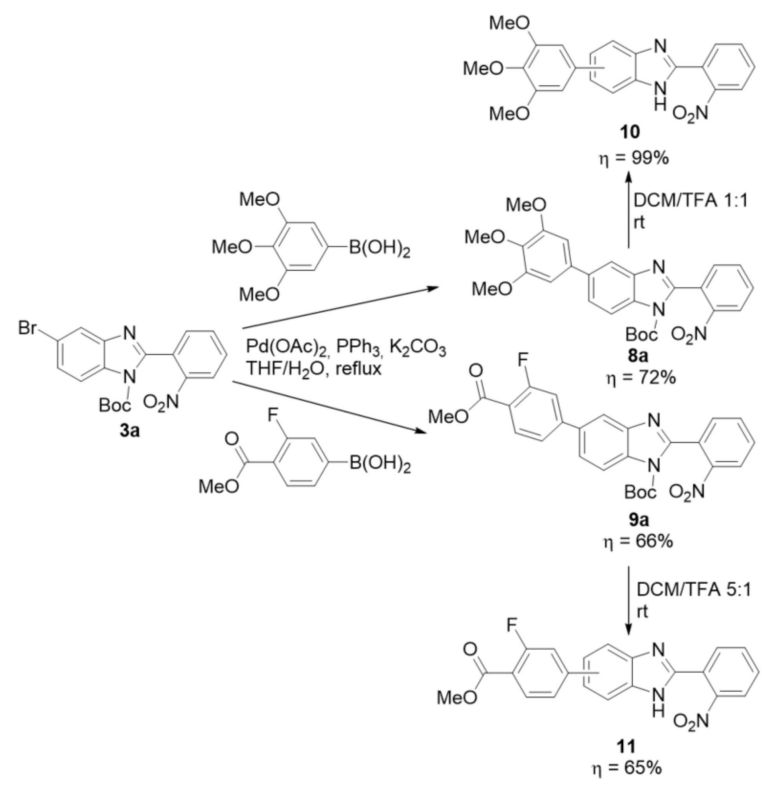

Scheme 3. Suzuki coupling involving boc-protected benzimidazole (3a), and subsequent deprotection. 
For 8a, deprotection was performed under the usual trifluoroacetic acid (TFA)/ dichloromethane (DCM) 1:1 for $2 \mathrm{~h}$, resulting in quantitative yield of product 10. For 9a, due to the presence of the methyl ester group, we decided to use TFA/DCM 1:5 (5 h) and, following purification, 11 was obtained in $65 \%$ yield.

It should be noted that in the amination reaction of 3a with 3-(methylsulfonyl)aniline (Scheme 4), using the reaction conditions described above, without isolation of the protected product, we obtained product 12 in 48\% isolated yield. This slightly lower yield may be attributed to partial deprotection of the boc group during the reaction, since carbamates are much easier to cleave under basic conditions with less basic amines such as imidazole or benzimidazole [53]. Therefore, the boc-protected product was not isolated, and we proceeded directly to the deprotection step. When the reaction was finished, the solid was filtered, the solvent was evaporated and the solid was re-dissolved in a mixture of TFA/DCM 1:1 for $2 \mathrm{~h}$. After basic work-up to neutralize the acid, product $\mathbf{1 2}$ was purified by column chromatography, and isolated in $48 \%$ yield.

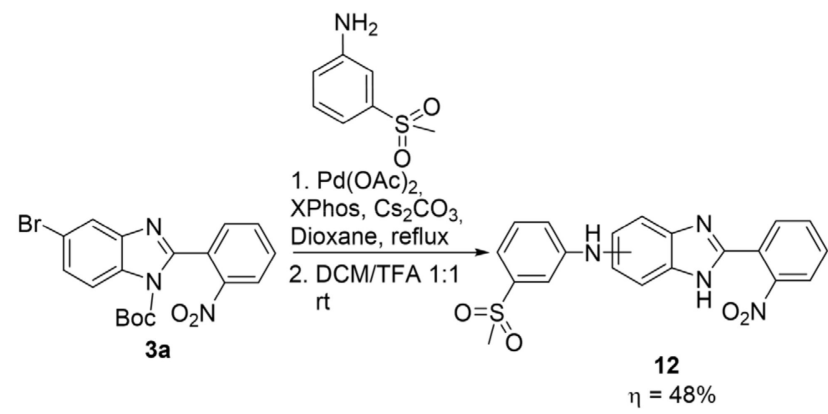

Scheme 4. Buchwald-Hartwig coupling involving boc-protected benzimidazole (3a), and subsequent deprotection.

Finally, to prepare our initially designed compounds (Table 1) with all the appropriate functional groups, according to the pharmacophore model developed, a catalytic hydrogenation of the nitrophenyl group was the final step of the synthetic route (Scheme 5). Briefly, the substrate, $\mathrm{NH}_{2} \mathrm{NH}_{2} \cdot \mathrm{H}_{2} \mathrm{O}$, and $\mathrm{Pd} / \mathrm{C}$ were mixed in $\mathrm{MeOH}$. The reaction was conducted at reflux temperature for 10-30 $\mathrm{min}$, then filtered, and the solvent was evaporated, to give 13 in 91\% yield, 14 in 56\% yield (contaminated with dimeric amide in 25\%, see Supplementary Materials: Figure S55), and 15 in 80\% yield. These new chemical entities show a good match to our initially proposed computational model (ChemScore of 33.7, 28.7 and 27.5 for compounds 15, 14, and 13, respectively).

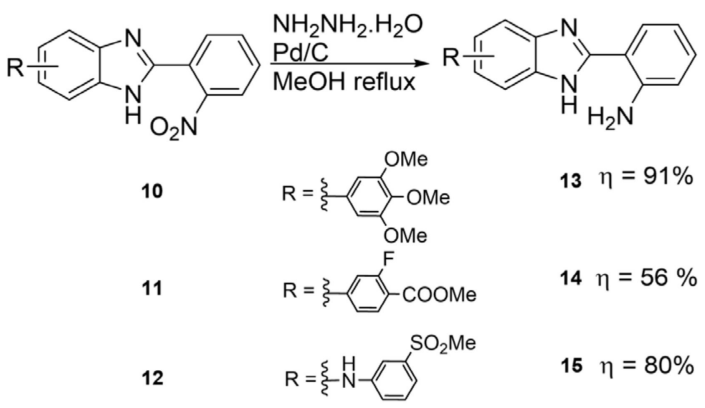

Scheme 5. Pd/C catalyzed reduction of compounds 10-12 using hydrazine monohydrat.

\section{Materials and Methods}

\subsection{Generation of the Pharmacophore Model}

Through a comprehensive literature search [9,10,35-41], several ligands of the E. coli DNA gyrase subunit B with different affinities were identified. From a total of 145 compounds, 61 were classified as actives $\left(\mathrm{IC}_{50} \leq 1.0 \mu \mathrm{M}\right), 54$ as intermediates $\left(1.0 \mu \mathrm{M}<\mathrm{IC}_{50}<100 \mu \mathrm{M}\right)$ 
and 30 as inactives $\left(\mathrm{IC}_{50} \geq 100 \mu \mathrm{M}\right)$. From the actives dataset, the most structurally diverse 18 compounds were selected as the training set while the remaining 43 were included in the test set. In cases where multiple derivatives were present, the compound with the highest activity was chosen. For the purpose of generating the pharmacophore queries, Molecular Operating Environment (MOE) 2018.0802 software [11] was used, using the Unified annotation scheme. After the training set ligands' structural alignment, common features were identified using MOE's Unified annotation scheme. From a set of about 50 pharmacophoric queries generated through variation of feature type, number, and radii, the best model was selected based on their performance in discriminating between actives and inactives in the test sets.

\subsection{Docking Studies on E. coli DNA GyrB}

Docking studies were performed in GOLD 5.4 (Cambridge Crystallographic Data Centre, Cambridge, UK) [43], using E. coli's DNA Gyrase subunit B ATPase binding domain crystallographic structure (PDB entry 4KFG) [42]. For protein preparation, hydrogen atoms were added to the binding site residues and correct tautomers and protonation states were assigned. Water molecules and the ligand were deleted from the crystal structure before the docking studies. The binding site region was defined as the amino acid residues within a radius of $15 \AA$ around the THR165 residue. To validate our protocol, the crystal structure ligand was docked into the defined binding site and the best scoring pose was able to reproduce the crystallographic pose with a root-mean-square deviation (RMSD) value of $0.57 \AA$. A set of 10 structurally diverse compounds with varying values of $\mathrm{IC}_{50}$ was docked using the defined protocol. The following scoring functions were tested: ChemScore, GOLDscore, and ChemPLP. The scoring function that yielded a better docking score correlation with experimental $\mathrm{IC}_{50}$ (ChemScore) was selected. From a set containing 6681 computationally generated derivatives of 2-aminophenyl-5(6)-substituted benzimidazoles, GOLD's ChemScore function was used to rank their predicted inhibitory activity. The best scoring poses were then graphically analyzed in MOE and the relevant protein side-chain interactions were determined.

\subsection{General Synthetic Methods}

All reagents were purchased from commercial sources and used without further purification. Non-deuterated solvents (dichloromethane, ethyl acetate, hexane, 1,4-dioxane, ethanol, THF, methanol) and deuterated solvents $\left(\mathrm{CDCl}_{3}, \mathrm{CD}_{3} \mathrm{OD}\right.$, DMSO- $d_{6}$ or acetone- $\left.d_{6}\right)$ were purchased from Sigma-Aldrich (Lisbon, Portugal). Benzyl bromide, Montmorillonite $\mathrm{K} 10, \mathrm{Cs}_{2} \mathrm{CO}_{3}, \mathrm{Pd}(\mathrm{OAc})_{2}, \mathrm{PPh}_{3}$, Sodium, benzophenone, DMAP, tetra- $n$-butylammonium iodide, di-tert-butyl dicarbonate and silica gel powder/plates were also purchased from Sigma-Aldrich (Lisbon, Portugal). $\mathrm{CaCl}_{2}, \mathrm{NaH}, 3,4,5$-trimethoxyphenylboronic acid, $\mathrm{K}_{2} \mathrm{CO}_{3}$, $\mathrm{Na}_{2} \mathrm{SO}_{4}, \mathrm{NaHCO}_{3}, 3$-fluoro-4-(methoxycarbonyl)phenylboronic acid, 4-(methylsulfonyl)aniline, 4-bromo-1,2-benzenediamine, Pd/C 5\% were purchased from Fluorochem (Derbyshire, United Kingdom). 2-nitrobenzaldehyde was purchased from Alfa Aesar (Lancashire, United Kingdom). 3-(methylsulfonyl)aniline was purchased from Apollo Scientific (Cheshire, United Kingdom). ${ }^{1} \mathrm{H}$ NMR and ${ }^{13} \mathrm{C}$ NMR spectra were recorded on a Bruker Avance 400 spectrometer (Chemistry Department, University of Coimbra, Portugal) at 400 and $101 \mathrm{MHz}$, respectively. ${ }^{1} \mathrm{H}$ and ${ }^{13} \mathrm{C} \mathrm{NMR}$ spectra were acquired in $\mathrm{CDCl}_{3}, \mathrm{CD}_{3} \mathrm{OD}, \mathrm{DMSO}-d_{6}$ or acetone- $d_{6}$, and the signals were referenced using the solvent peak or tetramethylsilane as an internal standard. High-resolution mass spectrometry (HRMS) analyses were conducted on a Bruker Microtof (Unidade de Espectrometría de Masas e Proteómica, Universidade de Santiago de Compostela, Spain). NMR and HRMS spectra are presented for all compounds in SI. All the reactions were monitored by thin-layer chromatography (TLC) using GF254 silica gel-coated TLC plates. Dichloromethane, ethyl acetate and hexane were distilled over anhydrous $\mathrm{CaCl}_{2}$ prior to use. 1,4-dioxane was dried using $\mathrm{Na}$ /benzophenone and stored over $4 \AA$ molecular sieves. For the Pd-catalyzed coupling reactions, all solvents were 
subjected to at least three cycles of the freeze-pump-thaw degassing method prior to the reaction, and the reactions were performed under inert atmosphere.

Procedures for the Synthesis of Products

5(6)-bromo-2-(2-nitrophenyl)-1H-benzimidazole (1):

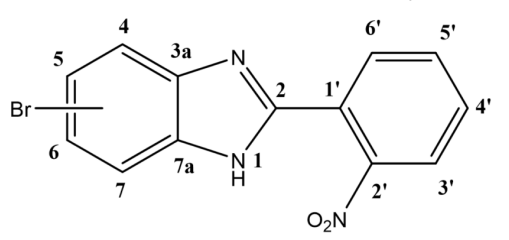

In a round-bottom flask, 4-bromo-1,2-benzenediamine (2.5 g; $13.4 \mathrm{mmol})$, 2-nitrobenzaldehyde ( $2.23 \mathrm{~g} ; 14.8 \mathrm{mmol})$, and $250 \mathrm{mg}$ of Montmorillonite $\mathrm{K} 10$ were mixed in ethanol $(30 \mathrm{~mL})$. The reaction was stirred at room temperature for $4 \mathrm{~h}$. The mixture was filtered, the solvent was evaporated, and the dark orange slurry obtained was dissolved in ethyl acetate, followed by the addition of silica powder and the evaporation of the solvent to dryness. The resulting solid was loaded in a silica column, and the crude was purified dichloromethane/ethyl acetate 10:1 $\left(\mathrm{R}_{\mathrm{f}}=0.33\right)$. The product was obtained as a yellow solid in $62 \%$ yield $(2.64 \mathrm{~g})$. Characterization data in accordance to literature [45]. ${ }^{1} \mathrm{H}$ NMR (400 MHz, DMSO- $\left.d_{6}\right)$ ppm: 14.50-12.00 (brs, $\left.1 \mathrm{H}_{1}\right), 8.05\left(\mathrm{dd}, J=8.0,1.3 \mathrm{~Hz}, 1 \mathrm{H}_{3^{\prime}}\right), 7.97\left(\mathrm{dd}, J=7.8,1.5 \mathrm{~Hz}, 1 \mathrm{H}_{6^{\prime}}\right), 7.88$ $\left(\mathrm{td}, J=7.6,1.3 \mathrm{~Hz}, 1 \mathrm{H}_{5^{\prime}}\right), 7.82\left(\mathrm{~d}, J=1.9 \mathrm{~Hz}, 1 \mathrm{H}_{4 / 7}\right), 7.78\left(\mathrm{td}, J=7.8,1.5 \mathrm{~Hz}, 1 \mathrm{H}_{4^{\prime}}\right), 7.59(\mathrm{~d}$, $\left.J=8.5 \mathrm{~Hz}, 1 \mathrm{H}_{7 / 4}\right), 7.39\left(\mathrm{dd}, J=8.5,2.0 \mathrm{~Hz}, 1 \mathrm{H}_{6 / 5}\right) ;{ }^{13} \mathrm{C}$ NMR $\left(101 \mathrm{MHz}, \mathrm{DMSO}-d_{6}\right)$ ppm: $148.9\left(\mathrm{C}^{\prime}\right), 148.7(\mathrm{C} 2), 132.8\left(\mathrm{C}^{\prime}\right), 131.2\left(\mathrm{C}^{\prime}\right), 131.1\left(\mathrm{C}^{\prime}\right), 125.4(\mathrm{C} 6 / 5), 124.4\left(\mathrm{C}^{\prime}\right), 123.9$ $\left(\mathrm{C}^{\prime}\right), 118.1$ (C4/7), 116.5 (C7/4), 114.7 (C5/6); HRMS (ESI-TOF) calcd. for $\mathrm{C}_{13} \mathrm{H}_{9} \mathrm{BrN}_{3} \mathrm{O}_{2}$ : $[\mathrm{M}+\mathrm{H}]^{+}: 317.9878$, found 317.9877 .

1-benzyl-5(6)-bromo-2-(2-nitrophenyl)-1H-benzimidazole (2): In an oven-dried Schlenk tube coupled with a condenser, 5-bromo-2-(2-nitrophenyl)-1H-benzimidazole (2.5 g, $7.86 \mathrm{mmol})$ was dissolved in dry THF $(5 \mathrm{~mL})$. The system was degassed with $5 x$ vacuum/argon cycles. To the stirring solution at $0{ }^{\circ} \mathrm{C}, \mathrm{NaH}(60 \%$ in mineral oil) $(226 \mathrm{mg}, 9.43 \mathrm{mmol})$ was slowly added under an argon flow. After the evolution of the hydrogen gas, benzyl bromide $(1.12 \mathrm{~mL}, 9.43 \mathrm{mmol})$ and a catalytic amount of tetra- $n$-butylammonium iodide were added. The mixture was heated at reflux temperature $\left(70^{\circ} \mathrm{C}\right)$ for $2 \mathrm{~h}$. After cooling, the reaction was quenched with methanol, and the solvent was evaporated. The crude was purified by column chromatography using dichloromethane/ethyl acetate 1:20 $\left(R_{\mathrm{f}}=0.40\right)$. The isomer mixture was obtained as a yellow solid in $87 \%$ yield $(2.8 \mathrm{~g}) .{ }^{1} \mathrm{H}$ NMR $\left(400 \mathrm{MHz}, \mathrm{CDCl}_{3}\right)(1: 1$ mixture of regioisomers) ppm: $8.17-8.10\left(\mathrm{~m}, 1 \mathrm{H}_{\mathrm{Ar}}\right), 7.89\left(\mathrm{~d}, J=1.8 \mathrm{~Hz}, 0.5 \mathrm{H}_{\mathrm{Ar}}\right), 7.65-7.59$ $\left(\mathrm{m}, 2.5 \mathrm{H}_{\mathrm{Ar}}\right), 7.44-7.33\left(\mathrm{~m}, 2 \mathrm{H}_{\mathrm{Ar}}\right), 7.30\left(\mathrm{dd}, J=8.6,1.7 \mathrm{~Hz}, 0.5 \mathrm{H}_{\mathrm{Ar}}\right), 7.22-7.16\left(\mathrm{~m}, 3 \mathrm{H}_{\mathrm{Ar}}\right), 7.03$ $\left(\mathrm{d}, J=1.8 \mathrm{~Hz}, 0.5 \mathrm{H}_{\mathrm{Ar}}\right), 6.96-6.90\left(\mathrm{~m}, 2 \mathrm{H}_{\mathrm{Ar}}\right), 5.03\left(\mathrm{~m}, 2 \mathrm{H}_{\text {benzyl }}\right) ;{ }^{13} \mathrm{C} \mathrm{NMR}\left(101 \mathrm{MHz}, \mathrm{CDCl}_{3}\right)$ (1:1 mixture of regioisomers) ppm: 150.9, 150.5, 148.8, 144.1, 141.8, 136.2, 135.1, 135.0, 134.1, 133.6, 133.5, 132.73, 132.70, 131.58, 131.56, 129.2, 129.1, 128.41, 128.38, 126.8, 126.76, 126.72, 126.4, 125.38, 125.4, 125.2, 125.1, 123.1, 121.5, 117.0, 116.0, 113.8, 112.1, 48.7, 48.6; HRMS (ESI-TOF) calcd. for $\mathrm{C}_{20} \mathrm{H}_{15} \mathrm{BrN}_{3} \mathrm{O}_{2}:[\mathrm{M}+\mathrm{H}]^{+}:$408.0348, found 408.0345.

General procedure for synthesis, isolation and characterization of 1-boc-5-bromo-2-(2nitrophenyl)-benzimidazole (3a) and 1-boc-6-bromo-2-(2-nitrophenyl)-benzimidazole (3b): In a round-bottom flask, 5-bromo-2-(2-nitrophenyl)- $1 H$-benzimidazole (1.66 g, $5.22 \mathrm{mmol}$ ), di-tert-butyl dicarbonate $(2.28 \mathrm{~g}, 10.44 \mathrm{mmol})$ and DMAP $(638 \mathrm{mg}, 5.22 \mathrm{mmol})$ were mixed in dichloromethane $(30 \mathrm{~mL})$, and the reaction was left stirring at room temperature for $24 \mathrm{~h}$. The solvent was evaporated, and the product was purified by column chromatography using hexane/ethyl acetate $4: 1$ as eluent $\left(R_{f}=0.40\right.$ for $3 a R_{f}=0.27$ for $\left.3 b\right)$. Two pure fractions of light yellow solids (isomers $\mathbf{3} \mathbf{a}$ and $\mathbf{3 b}$ ) were obtained in a 1:1 ratio with an overall yield of $89 \%$ (1.95 g).

1-boc-5-bromo-2-(2-nitrophenyl)-benzimidazole (3a): 


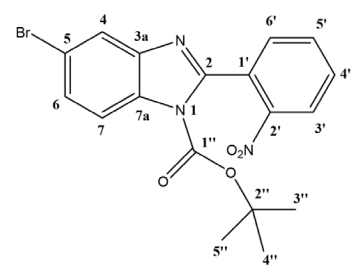

${ }^{1} \mathrm{H}$ NMR $\left(400 \mathrm{MHz}, \mathrm{CDCl}_{3}\right)$ ppm: $8.30\left(\mathrm{dd}, J=8.2,1.3 \mathrm{~Hz}, 1 \mathrm{H}_{3^{\prime}}\right), 7.95\left(\mathrm{~d}, J=8.7 \mathrm{~Hz}, 1 \mathrm{H}_{7}\right)$, $7.92\left(\mathrm{~d}, J=1.9 \mathrm{~Hz}, 1 \mathrm{H}_{4}\right), 7.79\left(\mathrm{td}, J=7.5,1.3 \mathrm{~Hz}, 1 \mathrm{H}_{5^{\prime}}\right), 7.70\left(\mathrm{td}, J=7.9,1.5 \mathrm{~Hz}, 1 \mathrm{H}_{4^{\prime}}\right)$, $7.64\left(\mathrm{dd}, J=7.5,1.6 \mathrm{~Hz}, 1 \mathrm{H}_{6^{\prime}}\right), 7.54\left(\mathrm{dd}, J=8.7,1.9 \mathrm{~Hz}, 1 \mathrm{H}_{6}\right), 1.37\left(\mathrm{~s}, 9 \mathrm{H}_{3^{\prime \prime}-5^{\prime \prime}}\right) .{ }^{13} \mathrm{C} \mathrm{NMR}$ (101 MHz, $\mathrm{CDCl}_{3}$ ) ppm: 151.0 (C2), $147.8\left(\mathrm{C1}^{\prime \prime}\right), 147.7\left(\mathrm{C2}^{\prime}\right), 144.0(\mathrm{C} 3 \mathrm{a}), 133.9\left(\mathrm{C5}^{\prime}\right), 132.2$ (C7a), $132.1\left(\mathrm{C}^{\prime}\right), 130.8\left(\mathrm{C}^{\prime}\right), 128.8\left(\mathrm{C1}^{\prime}\right), 128.7$ (C6), $124.7\left(\mathrm{C}^{\prime}\right), 123.4$ (C4), 117.7 (C5), 116.7 (C7), $86.4\left(\mathrm{C2}^{\prime \prime}\right), 27.7$ (C3",C4",C5"); Assignment of regioisomer was done using 2D-NMR, see Supplementary Materials: Figure S18;

1-boc-6-bromo-2-(2-nitrophenyl)-benzimidazole (3b):<smiles>Cc1ccc2cc3c(cc2c1)C(=O)[C@H](C(C)(C)C)c1ccccc1-3</smiles>

${ }^{1} \mathrm{H}$ NMR $\left(400 \mathrm{MHz}, \mathrm{CDCl}_{3}\right)$ ppm: $8.30\left(\mathrm{dd}, J=8.2,1.3 \mathrm{~Hz}, 1 \mathrm{H}_{3^{\prime}}\right), 8.28\left(\mathrm{~d}, J=1.9 \mathrm{~Hz}, 1 \mathrm{H}_{7}\right)$, $7.79\left(\mathrm{td}, J=7.5,1.3 \mathrm{~Hz}, 1 \mathrm{H}_{5^{\prime}}\right), 7.70\left(\mathrm{td}, J=7.9,1.5 \mathrm{~Hz}, 1 \mathrm{H}_{4^{\prime}}\right), 7.65\left(\mathrm{dd}, J=7.5,1.5 \mathrm{~Hz}, 1 \mathrm{H}_{6^{\prime}}\right)$, $7.64\left(\mathrm{~d}, J=8.5,1 \mathrm{H}_{4}\right), 7.52\left(\mathrm{dd}, J=8.5,1.9 \mathrm{~Hz}, 1 \mathrm{H}_{5}\right), 1.37\left(\mathrm{~s}, 9 \mathrm{H}_{3^{\prime \prime}-5^{\prime \prime}}\right) .{ }^{13} \mathrm{C} \mathrm{NMR}(101 \mathrm{MHz}$, $\mathrm{CDCl}_{3}$ ) ppm: 150.2, 147.6, 147.6, 141.6, 133.9, 133.8, 132.0, 130.7, 128.7, 127.9, 124.6, 121.4, 119.0, 118.5, 86.4, 27.5; HRMS (ESI-TOF) calcd. for $\mathrm{C}_{18} \mathrm{H}_{17} \mathrm{BrN}_{3} \mathrm{O}_{4}$ : $[\mathrm{M}+\mathrm{H}]^{+}$: 418.0402, found 418.0403. Assignment of regioisomer was done using 2D-NMR, see Supplementary Materials: Figure S23.

1-benzyl-5(6)-(3,4,5-trimethoxyphenyl)-2-(2-nitrophenyl)-benzimidazole (4): In a Schlenk tube, 1-benzyl-5(6)-bromo-2-(2-nitrophenyl)-benzimidazole (500 $\mathrm{mg}, 1.22 \mathrm{mmol}$ ) and 3,4,5trimethoxyphenylboronic acid ( $526 \mathrm{mg}, 2.48 \mathrm{mmol}$ ) were dissolved in a mixture of THF/ $\mathrm{H}_{2} \mathrm{O}$ 4:1 (15 mL). Under an argon flow, $\mathrm{Pd}(\mathrm{OAc})_{2}(27 \mathrm{mg} ; 0.12 \mathrm{mmol}), \mathrm{PPh}_{3}(80 \mathrm{mg} ; 0.30 \mathrm{mmol})$ and $\mathrm{K}_{2} \mathrm{CO}_{3}(380 \mathrm{mg}, 9.2 \mathrm{mmol})$ were added and the reaction was heated to $70{ }^{\circ} \mathrm{C}$ for $16 \mathrm{~h}$. After cooling, ethyl acetate was added to the reaction, and the insoluble solid was filtered. The organic phase was then washed with a $1 \mathrm{M}$ solution of $\mathrm{NaOH}(5 \mathrm{x})$, followed by water $(2 \mathrm{x})$. After drying with $\mathrm{Na}_{2} \mathrm{SO}_{4}$ and filtering, the solvent was evaporated. Then, a column chromatography in silica gel was performed using dichloromethane/ethyl acetate $5: 1$ as eluent $\left(\mathrm{R}_{\mathrm{f}}=0.38\right)$. The isomer mixture was obtained as a yellow solid in $66 \%$ yield (399 mg). ${ }^{1} \mathrm{H}$ NMR (400 MHz, $\mathrm{CDCl}_{3}$ ) (1:1 mixture of regioisomers) ppm: 8.20-8.11 (m, $\left.1 \mathrm{H}_{\mathrm{Ar}}\right), 7.94\left(\mathrm{~d}, J=1.6 \mathrm{~Hz}, 0.5 \mathrm{H}_{\mathrm{Ar}}\right), 7.79\left(\mathrm{~d}, J=8.4 \mathrm{~Hz}, 0.5 \mathrm{H}_{\mathrm{Ar}}\right), 7.67-7.58\left(\mathrm{~m}, 2 \mathrm{H}_{\mathrm{Ar}}\right), 7.48-7.40$ $\left(\mathrm{m}, 2 \mathrm{H}_{\mathrm{Ar}}\right), 7.27-7.18\left(\mathrm{~m}, 4 \mathrm{H}_{\mathrm{Ar}}\right), 7.02-6.95\left(\mathrm{~m}, 2 \mathrm{H}_{\mathrm{Ar}}\right), 6.76\left(\mathrm{~s}, 1 \mathrm{H}_{\mathrm{Ar}}\right), 6.63\left(\mathrm{~s}, 1 \mathrm{H}_{\mathrm{Ar}}\right), 5.19(\mathrm{~s}$, $\left.1 \mathrm{H}_{\text {benzyl }}\right), 5.17\left(\mathrm{~s}, 1 \mathrm{H}_{\text {benzyl }}\right), 3.87-3.80\left(\mathrm{~m}, 9 \mathrm{H}_{\mathrm{OMe}}\right) ;{ }^{13} \mathrm{C} \mathrm{NMR}\left(101 \mathrm{MHz}, \mathrm{CDCl}_{3}\right)(1: 1$ mixture of regioisomers) ppm: 153.57, 153.55, 150.4, 150.3, 148.9, 137.71, 137.67, 137.5, 137.1, 135.6, 135.4, 135.3, 134.5, 133.54, 133.51, 132.83, 132.77, 131.54, 131.46, 129.12, 129.08, 128.3, 128.2, 126.9, 126.8, 125.7, 125.2, 125.1, 123.6, 122.9, 120.2, 118.4, 111.0, 109.3, 105.0, 104.9, 61.1, 56.3, 48.7; HRMS (ESI-TOF) calcd. for $\mathrm{C}_{29} \mathrm{H}_{26} \mathrm{~N}_{3} \mathrm{O}_{5}:[\mathrm{M}+\mathrm{H}]^{+}: 496.1872$, found 496.1870.

1-benzyl-5(6)-(3-fluoro-4-(methoxycarbonyl)phenyl)-2-(2-nitrophenyl)-benzimidazole (5): In a Schlenk tube, 1-benzyl-5(6)-bromo-2-(2-nitrophenyl)-benzimidazole ( $300 \mathrm{mg}, 0.74 \mathrm{mmol}$ ) and 3-fluoro-4-(methoxycarbonyl)phenylboronic acid (293 mg, $1.48 \mathrm{mmol}$ ) were dissolved in a mixture of THF $/ \mathrm{H}_{2} \mathrm{O} 4: 1(8 \mathrm{~mL})$. Under an argon flow, $\mathrm{Pd}(\mathrm{OAc})_{2}(16 \mathrm{mg} ; 0.074 \mathrm{mmol})$, $\mathrm{PPh}_{3}(48 \mathrm{mg} ; 0.18 \mathrm{mmol})$, and $\mathrm{K}_{2} \mathrm{CO}_{3}(100 \mathrm{mg}, 1.38 \mathrm{mmol})$ were added and the reaction was heated to $70^{\circ} \mathrm{C}$ for $16 \mathrm{~h}$. After cooling, ethyl acetate was added to the reaction, and the insoluble solid was filtered. The organic phase was then washed with water $(2 x)$. 
After drying with $\mathrm{Na}_{2} \mathrm{SO}_{4}$ and filtering, the solvent was evaporated. Then, a column chromatography in silica gel was performed using dichloromethane/ethyl acetate 5:1 as eluent $\left(R_{f}=0.38\right)$. The isomer mixture was obtained as a yellow solid in $80 \%$ yield $(286 \mathrm{mg})$. ${ }^{1} \mathrm{H}$ NMR (400 MHz, acetone- $\left.d_{6}\right)$ (1:1 mixture of regioisomers) ppm: $8.28-8.20\left(\mathrm{~m}, 1 \mathrm{H}_{\mathrm{Ar}}\right)$, $8.06\left(\mathrm{~d}, J=1.7 \mathrm{~Hz}, 0.5 \mathrm{H}_{\mathrm{Ar}}\right), 8.04-7.95\left(\mathrm{~m}, 1 \mathrm{H}_{\mathrm{Ar}}\right), 7.95\left(\mathrm{~d}, J=1.7 \mathrm{~Hz}, 0.5 \mathrm{H}_{\mathrm{Ar}}\right), 7.90-7.83(\mathrm{~m}$, $\left.2 \mathrm{H}_{\mathrm{Ar}}\right), 7.80\left(\mathrm{~d}, J=8.5 \mathrm{~Hz}, 0.5 \mathrm{H}_{\mathrm{Ar}}\right), 7.76-7.52\left(\mathrm{~m}, 4.5 \mathrm{H}_{\mathrm{Ar}}\right), 7.33-7.23\left(\mathrm{~m}, 3 \mathrm{H}_{\mathrm{Ar}}\right), 7.20-7.15(\mathrm{~m}$, $\left.2 \mathrm{H}_{\mathrm{Ar}}\right), 5.28\left(\mathrm{~s}, 1 \mathrm{H}_{\text {benzyl }}\right), 5.25\left(\mathrm{~s}, 1 \mathrm{H}_{\text {benzyl }}\right), 3.94\left(\mathrm{~s}, 1.5 \mathrm{H}_{\mathrm{OMe}}\right), 3.93\left(\mathrm{~s}, 1.5 \mathrm{H}_{\mathrm{OMe}}\right) ;{ }^{13} \mathrm{C} \mathrm{NMR}$ $\left(101 \mathrm{MHz}\right.$, acetone- $\left.d_{6}\right)(1: 1$ mixture of regioisomers) ppm: 165.0, 164.9, 164.9, 164.9, 164.3, 164.2, 161.7, 161.6, 152.0, 151.9, 150.4, 150.3, 149.3, 149.2, 149.1, 149.0, 144.9, 144.9, 137.2, $137.1,137.1,136.9,134.4,134.3,134.3,134.2,133.8,133.8,133.3,133.2,133.2,132.3,132.3$, $129.6,129.5,128.6,128.6,127.9,127.9,126.5,126.4,125.8,125.7,123.6,123.6,123.4,122.6$, $121.2,119.4,117.6,117.5,117.5,117.4,116.1,116.1,115.9,115.8,112.5,110.7,52.5,52.5,49.0$, 48.8; HRMS (ESI-TOF) calcd. for $\mathrm{C}_{28} \mathrm{H}_{21} \mathrm{FN}_{3} \mathrm{O}_{4}:[\mathrm{M}+\mathrm{H}]^{+}:$482.1516, found 482.1513.

1-benzyl-N-(4-(methylsulfonyl)phenyl)-2-(2-nitrophenyl)-1-benzimidazol-5(6)-amine (6): In a Schlenk tube, Pd(OAc) 2 (0.074 mmol, $16.5 \mathrm{mg})$, XPhos (0.11 mmol, $53 \mathrm{mg}), 1$-benzyl-5(6)bromo-2-(2-nitrophenyl)-benzimidazole (300 mg, $0.74 \mathrm{mmol}), 4$-(methylsulfonyl)aniline (151 mg, $0.88 \mathrm{mmol})$ and $\mathrm{Cs}_{2} \mathrm{CO}_{3}(1.47 \mathrm{mmol}, 479 \mathrm{mg})$ were added to dry dioxane $(5 \mathrm{~mL})$ and the temperature was set to $100{ }^{\circ} \mathrm{C}$. The reaction was carried out at reflux temperature for $16 \mathrm{~h}$. After cooling, the crude mixture was filtered and the solid was washed with acetone. The filtrate was evaporated and a column chromatography in silica gel was performed using dichloromethane/ethyl acetate 1:1 as eluent $\left(R_{\mathrm{f}}=0.29\right)$. After drying, a brown solid was obtained in $78 \%$ yield $(282 \mathrm{mg}) .{ }^{1} \mathrm{H}$ NMR $\left(400 \mathrm{MHz}\right.$, acetone- $\left.d_{6}\right):(1: 1$ mixture of regioisomers) ppm: 8.25-8.10 (m, 2 $\left.\mathrm{H}_{\mathrm{Ar}}\right), 7.90-7.80\left(\mathrm{~m}, 2 \mathrm{H}_{\mathrm{Ar}}\right), 7.80-7.55\left(\mathrm{~m}, 4 \mathrm{H}_{\mathrm{Ar}}\right), 7.42(\mathrm{~d}$, $\left.J=8.6 \mathrm{~Hz}, 0.5 \mathrm{H}_{\mathrm{Ar}}\right), 7.36-7.16\left(\mathrm{~m}, 6 \mathrm{H}_{\mathrm{Ar}}\right), 7.16-7.08\left(\mathrm{~m}, 1.5 \mathrm{H}_{\mathrm{Ar}}\right), 7.04\left(\mathrm{~d}, J=8.9 \mathrm{~Hz}, 1 \mathrm{H}_{\mathrm{Ar}}\right)$, $5.46\left(\mathrm{~s}, 1 \mathrm{H}_{\text {benzyl }}\right), 5.44\left(\mathrm{~s}, 1 \mathrm{H}_{\text {benzyl }}\right), 3.01\left(\mathrm{~s}, 3 \mathrm{H}_{\mathrm{Me}}\right) .{ }^{13} \mathrm{C} \mathrm{NMR}\left(101 \mathrm{MHz}\right.$, acetone- $\left.d_{6}\right)(1: 1$ mixture of regioisomers) ppm: 151.6, 151.3, 150.8, 150.6, 150.4, 145.1, 141.0, 137.6, 137.3, $136.9,136.8,134.21,134.15,133.4,133.3,133.2,132.2,132.1,130.8,130.4,130.1,130.0,129.62$, $129.57,128.6,127.91,127.87,126.60,126.56,125.73,125.70,121.4,119.9,118.4,114.5,114.2$, 114.1, 113.7, 112.5, 104.1, 48.9, 44.94, 44.88; HRMS (ESI-TOF) calcd. for $\mathrm{C}_{27} \mathrm{H}_{23} \mathrm{~N}_{4} \mathrm{O}_{4} \mathrm{~S}$ : $[\mathrm{M}+\mathrm{H}]^{+}:$499.1440, found 499.1434 .

1-benzyl-N-(3-(methylsulfonyl)phenyl)-2-(2-nitrophenyl)-benzimidazol-5(6)-amine (7): In a Schlenk tube, $\mathrm{Pd}(\mathrm{OAc})_{2}(0.074 \mathrm{mmol}, 16.5 \mathrm{mg})$, XPhos (0.11 mmol, $\left.53 \mathrm{mg}\right), 1$-benzyl-5(6)bromo-2-(2-nitrophenyl)-benzimidazole (300 mg, $0.74 \mathrm{mmol}), 3-($ methylsulfonyl)aniline (151 mg, $0.88 \mathrm{mmol})$ and $\mathrm{Cs}_{2} \mathrm{CO}_{3}(1.47 \mathrm{mmol}, 479 \mathrm{mg})$ were added to dry dioxane $(5 \mathrm{~mL})$ and the temperature was set to $100{ }^{\circ} \mathrm{C}$. The reaction was carried out at reflux temperature for $16 \mathrm{~h}$. After cooling, the crude mixture was filtered and the solid was washed with acetone. The filtrate was evaporated and a column chromatography in silica gel was performed using dichloromethane/ethyl acetate $1: 1$ as eluent $\left(R_{f}=0.23\right)$. After drying, a brown solid was obtained in $81 \%$ yield $(300 \mathrm{mg}) .{ }^{1} \mathrm{H}$ NMR $\left(400 \mathrm{MHz}\right.$, acetone- $\left.d_{6}\right)(1: 1$ mixture of regioisomers) ppm: $8.12\left(\mathrm{~s}, 1 \mathrm{H}_{\mathrm{Ar}}\right), 7.77\left(\mathrm{dd}, J=7.6,1.7 \mathrm{~Hz}, 1 \mathrm{H}_{\mathrm{Ar}}\right), 7.45-7.36(\mathrm{~m}$, $\left.2 \mathrm{H}_{\mathrm{Ar}}\right), 7.31\left(\mathrm{dd}, J=7.3,1.8 \mathrm{~Hz}, 1 \mathrm{H}_{\mathrm{Ar}}\right), 7.04-6.95\left(\mathrm{~m}, 4 \mathrm{H}_{\mathrm{Ar}}\right), 6.85-6.75\left(\mathrm{~m}, 5 \mathrm{H}_{\mathrm{Ar}}\right), 6.70-6.64$ $\left(\mathrm{m}, 3 \mathrm{H}_{\mathrm{Ar}}\right), 4.95\left(\mathrm{~m}, 2 \mathrm{H}_{\text {benzyl }}\right), 2.70\left(\mathrm{~s}, 3 \mathrm{H}_{\mathrm{Me}}\right) ;{ }^{13} \mathrm{C} \mathrm{NMR}\left(101 \mathrm{MHz}\right.$, acetone- $\left.d_{6}\right)(1: 1$ mixture of regioisomers) ppm: 149.7, 149.0, 146.3, 143.5, 141.8, 136.9, 136.3, 133.6, 132.2, 131.6, 131.2, 130.3, 128.6, 127.7, 127.0, 124.94, 124.93, 118.7, 117.6, 116.0, 111.9, 111.6, 109.9, 47.6, 43.7; HRMS (ESI-TOF) calcd. for $\mathrm{C}_{27} \mathrm{H}_{23} \mathrm{~N}_{4} \mathrm{O}_{4} \mathrm{~S}:[\mathrm{M}+\mathrm{H}]^{+}: 499.1440$, found 499.1436 .

1-boc-5-(3,4,5-trimethoxyphenyl)-2-(2-nitrophenyl)-benzimidazole (8a): In a Schlenk tube, 1-boc-5-bromo-2-(2-nitrophenyl)-benzimidazole $(300 \mathrm{mg}, 0.72 \mathrm{mmol})$ and 3,4,5trimethoxyphenylboronic acid $(229 \mathrm{mg}, 1.08 \mathrm{mmol})$ were dissolved in a mixture of $\mathrm{THF} / \mathrm{H}_{2} \mathrm{O}$ 4:1 (5 mL). Under an argon flow, $\mathrm{Pd}(\mathrm{OAc})_{2}(16 \mathrm{mg} ; 0.72 \mathrm{mmol}), \mathrm{PPh}_{3}(47 \mathrm{mg} ; 0.18 \mathrm{mmol})$, and $\mathrm{K}_{2} \mathrm{CO}_{3}(89 \mathrm{mg}, 2.2 \mathrm{mmol})$ were added and the reaction was heated to $70{ }^{\circ} \mathrm{C}$ for $16 \mathrm{~h}$. After cooling, ethyl acetate was added to the reaction, and the insoluble solid was filtered. The organic phase was then washed with a $1 \mathrm{M}$ solution of $\mathrm{NaOH}(5 \mathrm{x})$, followed by water (2x). After drying with $\mathrm{Na}_{2} \mathrm{SO}_{4}$ and filtering, the solvent was evaporated. Then, a column 
chromatography in silica gel was performed using a gradient mixture as eluent, starting with dichloromethane and ending in dichloromethane/ethyl acetate 20:1 $\left(R_{\mathrm{f}}=0.50\right)$. The light yellow solid was obtained in $72 \%$ yield $(260 \mathrm{mg}) .{ }^{1} \mathrm{H}$ NMR $\left(400 \mathrm{MHz}\right.$, acetone- $\left.d_{6}\right)$ ppm: $8.37-8.34\left(\mathrm{~m}, 1 \mathrm{H}_{\mathrm{Ar}}\right), 8.14\left(\mathrm{~d}, J=8.6 \mathrm{~Hz}, 1 \mathrm{H}_{\mathrm{Ar}}\right), 8.00-7.95\left(\mathrm{~m}, 2 \mathrm{H}_{\mathrm{Ar}}\right), 7.91-7.85(\mathrm{~m}$, $\left.2 \mathrm{H}_{\mathrm{Ar}}\right), 7.78\left(\mathrm{dd}, J=8.6,1.8 \mathrm{~Hz}, 1 \mathrm{H}_{\mathrm{Ar}}\right), 7.04\left(\mathrm{~s}, 2 \mathrm{H}_{\mathrm{Ar}}\right), 3.96\left(\mathrm{~s}, 6 \mathrm{H}_{\mathrm{OMe}}\right), 3.79\left(\mathrm{~s}, 3 \mathrm{H}_{\mathrm{OMe}}\right), 1.39$ $\left(\mathrm{s}, 9 \mathrm{H}_{\mathrm{boc}}\right) ;{ }^{13} \mathrm{C}$ NMR $\left(101 \mathrm{MHz}\right.$, acetone- $\left.d_{6}\right)$ ppm: 154.9, 151.3, 148.93, 148.91, 144.6, 139.1, 139.0, 137.6, 135.0, 133.5, 133.3, 131.8, 130.1, 125.5, 125.4, 119.2, 116.2, 105.8, 86.5, 60.73, 60.65, 56.7, 27.7; HRMS (ESI-TOF) calcd. for $\mathrm{C}_{27} \mathrm{H}_{28} \mathrm{~N}_{3} \mathrm{O}_{7}$ : $[\mathrm{M}+\mathrm{H}]^{+}:$506.1927, found 506.1924.

1-boc-5-(3-fluoro-4-(methoxycarbonyl)phenyl)-2-(2-nitrophenyl)-benzimidazole (9a): In a Schlenk tube, 1-boc-5-bromo-2-(2-nitrophenyl)-benzimidazole (300 mg, $0.74 \mathrm{mmol}$ ) and 3-fluoro-4-(methoxycarbonyl)phenylboronic acid (170 mg, $0.86 \mathrm{mmol}$ ) were dissolved in a mixture of THF $/ \mathrm{H}_{2} \mathrm{O} 4: 1(5 \mathrm{~mL})$. Under an argon flow, $\mathrm{Pd}(\mathrm{OAc})_{2}(16 \mathrm{mg} ; 0.074 \mathrm{mmol})$, $\mathrm{PPh}_{3}$ (48 mg; $\left.0.18 \mathrm{mmol}\right)$, and $\mathrm{K}_{2} \mathrm{CO}_{3}(298 \mathrm{mg}, 2.15 \mathrm{mmol})$ were added and the reaction was heated to $70{ }^{\circ} \mathrm{C}$ for $16 \mathrm{~h}$. After cooling, ethyl acetate was added to the reaction, and the insoluble solid was filtered. The organic phase was then washed with water $(2 x)$. After drying with $\mathrm{Na}_{2} \mathrm{SO}_{4}$ and filtering, the solvent was evaporated. Then, a column chromatography in silica gel was performed using dichloromethane as eluent $\left(\mathrm{R}_{\mathrm{f}}=0.36\right)$. The product was obtained as a yellow solid in $66 \%$ yield $(235 \mathrm{mg}) .{ }^{1} \mathrm{H}$ NMR $(400 \mathrm{MHz}$, acetone- $\left.d_{6}\right)$ ppm: $8.32\left(\mathrm{~d}, J=1.8 \mathrm{~Hz}, 1 \mathrm{H}_{\mathrm{Ar}}\right), 8.24\left(\mathrm{~d}, J=8.6 \mathrm{~Hz}, 1 \mathrm{H}_{\mathrm{Ar}}\right), 7.94(\mathrm{t}, J=7.9 \mathrm{~Hz}$, $\left.1 \mathrm{H}_{\mathrm{Ar}}\right), 7.86\left(\mathrm{td}, J=7.5,1.3 \mathrm{~Hz}, 1 \mathrm{H}_{\mathrm{Ar}}\right), 7.80-7.66\left(\mathrm{~m}, 4 \mathrm{H}_{\mathrm{Ar}}\right), 7.59\left(\mathrm{dd}, J=8.2,1.8 \mathrm{~Hz}, 1 \mathrm{H}_{\mathrm{Ar}}\right)$, $7.52\left(\mathrm{dd}, J=12.3,1.8 \mathrm{~Hz}, 1 \mathrm{H}_{\mathrm{Ar}}\right), 3.80\left(\mathrm{~s}, 6 \mathrm{H}_{\mathrm{OMe}}\right), 1.26\left(\mathrm{~s}, 9 \mathrm{H}_{\mathrm{boc}}\right) .{ }^{13} \mathrm{C} \mathrm{NMR}(101 \mathrm{MHz}$, acetone- $\left.d_{6}\right)$ ppm: $165.0(\mathrm{~d}, J=3.7 \mathrm{~Hz}), 163.1(\mathrm{~d}, J=258.1 \mathrm{~Hz}), 152.0,148.87(\mathrm{~d}, J=8.8 \mathrm{~Hz})$, $148.84,148.79,144.5,136.8(\mathrm{~d}, J=2.0 \mathrm{~Hz}), 135.1,134.8,133.7(\mathrm{~d}, J=1.7 \mathrm{~Hz}), 133.3,131.9$, $129.9,125.4,124.8,123.9(\mathrm{~d}, J=3.4 \mathrm{~Hz}), 121.6,118.2(\mathrm{~d}, J=10.6 \mathrm{~Hz}), 116.4(\mathrm{~d}, J=23.6 \mathrm{~Hz})$, 115.0, 86.8, 52.6, 27.7; HRMS (ESI-TOF) calcd. for $\mathrm{C}_{26} \mathrm{H}_{23} \mathrm{FN}_{3} \mathrm{O}_{6}:[\mathrm{M}+\mathrm{H}]^{+}:$492.1571, found 492.1564 .

5(6)-(3,4,5-trimethoxyphenyl)-2-(2-nitrophenyl)-1H-benzimidazole (10): In a round-bottom flask, 1-boc-5-(3,4,5-trimethoxyphenyl)-2-(2-nitrophenyl)- $1 H$-benzimidazole (0.28 mmol, $140 \mathrm{mg}$ ) was dissolved in a mixture of DCM/TFA 1:1 (2.0 mL). After $3 \mathrm{~h}$, the acid was neutralized by a slow addition of a saturated aqueous solution of $\mathrm{NaHCO}_{3}$. Dichloromethane was added and the organic phase was washed $2 x$ with a saturated solution of $\mathrm{NaHCO}_{3}$ and then $2 x$ with $\mathrm{H}_{2} \mathrm{O}$, followed by drying anhydrous $\mathrm{Na}_{2} \mathrm{SO}_{4}$, filtering and solvent evaporation. The product was purified by column chromatography in silica gel using DCM/Ethyl acetate $1: 2$ as eluent $\left(R_{\mathrm{f}}=0.37\right)$. After drying, a yellow solid was obtained in $99 \%$ yield (112 mg). ${ }^{1} \mathrm{H}$ NMR (400 MHz, DMSO-d $)_{6}$ ppm: 13.09 (brs, $\left.1 \mathrm{H}_{\mathrm{NH}}\right), 8.04(\mathrm{dd}, J=8.1,1.2 \mathrm{~Hz}$, $\left.1 \mathrm{H}_{\mathrm{Ar}}\right), 8.00\left(\mathrm{dd}, J=7.8,1.4 \mathrm{~Hz}, 1 \mathrm{H}_{\mathrm{Ar}}\right), 7.91-7.87\left(\mathrm{~m}, 2 \mathrm{H}_{\mathrm{Ar}}\right), 7.77\left(\mathrm{td}, J=7.8,1.4 \mathrm{~Hz}, 1 \mathrm{H}_{\mathrm{Ar}}\right)$, $7.67\left(\mathrm{~d}, J=8.4 \mathrm{~Hz}, 1 \mathrm{H}_{\mathrm{Ar}}\right), 7.59\left(\mathrm{dd}, J=8.5,1.7 \mathrm{~Hz}, 1 \mathrm{H}_{\mathrm{Ar}}\right), 6.97\left(\mathrm{~s}, 2 \mathrm{H}_{\mathrm{Ar}}\right), 3.89\left(\mathrm{~s}, 6 \mathrm{H}_{\mathrm{OMe}}\right)$, 3.70 (s, $\left.3 \mathrm{H}_{\text {boc }}\right) ;{ }^{13} \mathrm{C}$ NMR (101 MHz, DMSO-d ${ }_{6}$ ) ppm: 153.2, 149.0, 148.0, 136.80, 136.78, 135.3, 132.7, 131.0, 130.9, 124.3, 124.1, 122.2, 104.4, 60.1, 56.0; HRMS (ESI-TOF) calcd. for $\mathrm{C}_{22} \mathrm{H}_{20} \mathrm{~N}_{3} \mathrm{O}_{5}:[\mathrm{M}+\mathrm{H}]^{+}:$406.1403, found 406.1404 .

5(6)-(3-fluoro-4-(methoxycarbonyl)phenyl)-2-(2-nitrophenyl)-1H-benzimidazole (11): In a round-bottom flask, 1-boc-5-(3-fluoro-4-(methoxycarbonyl)phenyl)-2-(2-nitrophenyl)benzimidazole (0.42 mmol, $208 \mathrm{mg})$ was dissolved in DCM (2.0 mL) and TFA (0.4 mL) was added. After $5 \mathrm{~h}$, the acid was neutralized by a slow addition of a saturated aqueous solution of $\mathrm{NaHCO}_{3}$. Dicloromethane was added and the organic phase was washed $2 x$ with a saturated solution of $\mathrm{NaHCO}_{3}$ and then $2 x$ with $\mathrm{H}_{2} \mathrm{O}$, followed by drying anhydrous $\mathrm{Na}_{2} \mathrm{SO}_{4}$, filtering and solvent evaporation. The product was purified by column chromatography in silica gel using DCM/Ethyl acetate 6:1 as eluent $\left(R_{f}=0.27\right)$. After drying, a yellow solid was obtained in $65 \%$ yield $(107 \mathrm{mg}) .{ }^{1} \mathrm{H}$ NMR (400 MHz, acetone- $\left.d_{6}\right)$ ppm: $12.20-12.15\left(\mathrm{~m}, 1 \mathrm{H}_{\mathrm{NH}}\right), 8.09-7.93\left(\mathrm{~m}, 4 \mathrm{H}_{\mathrm{Ar}}\right), 7.88\left(\mathrm{td}, J=7.6,1.4 \mathrm{~Hz}, 1 \mathrm{H}_{\mathrm{Ar}}\right), 7.83-7.59$ $\left(\mathrm{m}, 5 \mathrm{H}_{\mathrm{Ar}}\right), 3.92\left(\mathrm{~s}, 3 \mathrm{H}_{\mathrm{OMe}}\right) ;{ }^{13} \mathrm{C} \mathrm{NMR}\left(101 \mathrm{MHz}\right.$, acetone- $\left.d_{6}\right) \mathrm{ppm}: 165.0(\mathrm{~d}, J=3.8 \mathrm{~Hz})$, $163.0(\mathrm{~d}, J=258.1 \mathrm{~Hz}), 150.5,149.9,149.3,133.5,133.4(\mathrm{~d}, J=1.7 \mathrm{~Hz}), 132.1,131.8,125.8$, 
125.3, $123.6(\mathrm{~d}, J=3.2 \mathrm{~Hz}), 117.4,116.0(\mathrm{~d}, J=23.4 \mathrm{~Hz}), 52.5$; HRMS (ESI-TOF) calcd. for $\mathrm{C}_{21} \mathrm{H}_{15} \mathrm{FN}_{3} \mathrm{O}_{4}:[\mathrm{M}+\mathrm{H}]^{+}:$392.1047, found 392.1042.

$N$-(3-(methylsulfonyl)phenyl)-2-(2-nitrophenyl)-1H-benzimidazol-5(6)-amine (12): In a Schlenk tube, Pd(OAc) 2 (0.072 mmol, $16.1 \mathrm{mg})$, XPhos (0.11 mmol, $52 \mathrm{mg}), 1$-benzyl-5(6)bromo-2-(2-nitrophenyl)-benzimidazole (300 mg, $0.72 \mathrm{mmol}), 3-($ methylsulfonyl)aniline $(147 \mathrm{mg}, 0.86 \mathrm{mmol})$ and $\mathrm{Cs}_{2} \mathrm{CO}_{3}(1.43 \mathrm{mmol}, 467 \mathrm{mg})$ were added to dry dioxane $(5 \mathrm{~mL})$ and the temperature was set to $100^{\circ} \mathrm{C}$. The reaction was carried out at reflux temperature for $16 \mathrm{~h}$. After cooling, the crude mixture was filtered and the solid was washed with acetone. The filtrate was evaporated and dissolved in a mixture of DCM/TFA 1:1 (4.0 mL). After $2 \mathrm{~h}$, the acid was neutralized by a slow addition of a saturated aqueous solution of $\mathrm{NaHCO}_{3}$. Ethyl acetate was added to the mixture, and the organic phase was washed $2 x$ with a saturated solution of $\mathrm{NaHCO}_{3}$ and then $2 x$ with $\mathrm{H}_{2} \mathrm{O}$. The organic phase was dried with anhydrous $\mathrm{Na}_{2} \mathrm{SO}_{4}$, filtered, and evaporated. A purification by column chromatography in silica gel was performed using dichloromethane/ethyl acetate $1: 1$ as eluent $\left(R_{f}=0.38\right)$. After drying, a brown solid was obtained in $48 \%$ yield $(140 \mathrm{mg}) .{ }^{1} \mathrm{H} \mathrm{NMR}(400 \mathrm{MHz}$, acetone- $d_{6}$ ) ppm: 11.95 (brs, $\left.1 \mathrm{H}_{\mathrm{NH}}\right), 8.02\left(\mathrm{dd}, J=7.7,1.5 \mathrm{~Hz}, 1 \mathrm{H}_{\mathrm{Ar}}\right), 7.98(\mathrm{dd}, J=8.1,1.3 \mathrm{~Hz}$, $\left.1 \mathrm{H}_{\mathrm{Ar}}\right), 7.90-7.80\left(\mathrm{~m}, 2 \mathrm{H}_{\mathrm{Ar}}\right), 7.74\left(\mathrm{~m}, 1 \mathrm{H}_{\mathrm{Ar}}\right), 7.65-7.55\left(\mathrm{~m}, 2 \mathrm{H}_{\mathrm{Ar}}\right), 7.47\left(\mathrm{~s}, 1 \mathrm{H}_{\mathrm{Ar}}\right), 7.44(\mathrm{~d}$, $\left.J=7.9 \mathrm{~Hz}, 1 \mathrm{H}_{\mathrm{Ar}}\right), 7.35\left(\mathrm{~d}, J=8.2 \mathrm{~Hz}, 1 \mathrm{H}_{\mathrm{Ar}}\right), 7.31\left(\mathrm{~d}, J=7.7 \mathrm{~Hz}, 1 \mathrm{H}_{\mathrm{Ar}}\right), 7.16(\mathrm{~d}, J=8.6 \mathrm{~Hz}$, $\left.1 \mathrm{H}_{\mathrm{Ar}}\right), 3.08\left(\mathrm{~s}, 3 \mathrm{H}_{\mathrm{Me}}\right) ;{ }^{13} \mathrm{C} \mathrm{NMR}\left(101 \mathrm{MHz}\right.$, acetone- $\left.d_{6}\right)$ ppm: 150.4, 143.4, 133.3, 131.8, 131.4, $131.1,125.9,125.2,117.8,113.7,44.3$; HRMS (ESI-TOF) calcd. for $\mathrm{C}_{20} \mathrm{H}_{17} \mathrm{~N}_{4} \mathrm{O}_{4} \mathrm{~S}:[\mathrm{M}+\mathrm{H}]^{+}$: 409.0971, found 409.0964 .

2-(2-aminophenyl)-5(6)-(3,4,5-trimethoxyphenyl)-1H-benzimidazole (13): In a round-bottom flask, 5(6)-(3,4,5-trimethoxyphenyl)-2-(2-nitrophenyl)-1H-benzimidazole (50 mg, $0.125 \mathrm{mmol}$ ), hydrazine monohydrate $(45 \mu \mathrm{L}, 1.25 \mathrm{mmol})$ and $\mathrm{Pd} / \mathrm{C} 5 \%(10 \mathrm{mg})$ were mixed in methanol $(1.0 \mathrm{~mL})$. The solution was stirred for $30 \mathrm{~min}$ at reflux temperature $\left(70{ }^{\circ} \mathrm{C}\right)$. The resulting solution was filtrated and the solvent evaporated. A white solid was obtained in $91 \%$ yield (43 mg). ${ }^{1} \mathrm{H}$ NMR (400 MHz, CD $\left.3 \mathrm{OD}\right)$ ppm: 7.77 (brs, $1 \mathrm{H}_{\mathrm{Ar}}$ ), 7.72 (dd, J = 7.8, 1.3 $\left.\mathrm{Hz}, 1 \mathrm{H}_{\mathrm{Ar}}\right), 7.61$ (brs, $\left.1 \mathrm{H}_{\mathrm{Ar}}\right), 7.48\left(\mathrm{dd}, J=8.3,1.7 \mathrm{~Hz}, 1 \mathrm{H}_{\mathrm{Ar}}\right), 7.19(\mathrm{ddd}, J=8.4,7.2,1.5 \mathrm{~Hz}$, $\left.1 \mathrm{H}_{\mathrm{Ar}}\right), 6.88\left(\mathrm{dd}, J=8.2,1.2 \mathrm{~Hz}, 1 \mathrm{H}_{\mathrm{Ar}}\right), 6.75\left(\mathrm{ddd}, J=8.2,7.1,1.2 \mathrm{~Hz}, 1 \mathrm{H}_{\mathrm{Ar}}\right), 3.92\left(\mathrm{~s}, 6 \mathrm{H}_{\mathrm{OMe}}\right)$, 3.81 (s, 3H $\left.\mathrm{OMe}_{\mathrm{OM}}\right) ;{ }^{13} \mathrm{C}$ NMR (101 MHz, CD $\left.3 \mathrm{OD}\right)$ ppm: 154.8, 154.7, 149.1, 139.7, 138.4, 131.8, $128.6,123.1,117.9,117.7,113.2,105.8,61.2,56.7$; HRMS (ESI-TOF) calcd. for $\mathrm{C}_{22} \mathrm{H}_{22} \mathrm{~N}_{3} \mathrm{O}_{3}$ : $[\mathrm{M}+\mathrm{H}]^{+}:$376.1661, found 376.1655.

2-(2-aminophenyl)-5(6)-(3-fluoro-4-(methoxycarbonyl)phenyl)-1H-benzimidazole (14): In a round-bottom flask, 5(6)-(3-fluoro-4-(methoxycarbonyl)phenyl)-2-(2-nitrophenyl)- $1 \mathrm{H}$ benzimidazole $(20 \mathrm{mg}, 0.051 \mathrm{mmol})$, hydrazine monohydrate $(25 \mu \mathrm{L}, 0.75 \mathrm{mmol})$ and $\mathrm{Pd} / \mathrm{C}$ $5 \%(2 \mathrm{mg})$ were mixed in methanol $(2.0 \mathrm{~mL})$. The solution was stirred for $1 \mathrm{~h}$ at reflux temperature $\left(70{ }^{\circ} \mathrm{C}\right)$. The product precipitated on the reaction mixture, and thus the crude was filtrated and the filtrate was dissolved in DMF. After evaporation of the solvent, a yellow solid was obtained in $56 \%$ yield $(15.7 \mathrm{mg}) .{ }^{1} \mathrm{H}$ NMR $\left(400 \mathrm{MHz}, \mathrm{DMSO}-d_{6}\right) \mathrm{ppm}$ : $12.83\left(\mathrm{brs}, 1 \mathrm{H}_{\mathrm{NH}}\right), 8.13-7.54\left(\mathrm{~m}, 7 \mathrm{H}_{\mathrm{Ar}}\right), 7.29\left(\mathrm{brs}, 2 \mathrm{H}_{\mathrm{Ar}}\right), 7.18\left(\mathrm{t}, J=7.7 \mathrm{~Hz}, 1 \mathrm{H}_{\mathrm{Ar}}\right), 6.85(\mathrm{~d}$, $\left.J=8.2 \mathrm{~Hz}, 1 \mathrm{H}_{\mathrm{Ar}}\right), 6.67\left(\mathrm{t}, J=7.5,1 \mathrm{H}_{\mathrm{Ar}}\right), 3.88\left(\mathrm{~s}, 3 \mathrm{H}_{\mathrm{OMe}}\right) ;{ }^{13} \mathrm{C}$ NMR $\left(101 \mathrm{MHz}, \mathrm{DMSO}-d_{6}\right)$ ppm: 164.0, $161.8(\mathrm{~d}, J=295 \mathrm{~Hz}), 154.0(\mathrm{~d}, J=24 \mathrm{~Hz}), 148.4,143.7,134.3,132.3,130.7,127.4$, 122.6, 121.9, 121.1, 118.6, 116.2, 115.0, 111.3, 109.7 (d, $J=6.8 \mathrm{~Hz}$ ), 52.3; HRMS (ESI-TOF) calcd. for $\mathrm{C}_{21} \mathrm{H}_{16} \mathrm{FN}_{3} \mathrm{O}_{2}:[\mathrm{M}+\mathrm{H}]^{+}:$362.1305, found 362.1310 .

2-(2-aminophenyl)- $N$-(3-(methylsulfonyl)phenyl)-1H-benzimidazol-5(6)-amine (15): In a round-bottom flask, $N$-(3-(methylsulfonyl)phenyl)-2-(2-nitrophenyl)-1H-benzimidazol5(6)-amine (40 mg, $0.098 \mathrm{mmol})$, hydrazine monohydrate $(50 \mu \mathrm{L}, 1.5 \mathrm{mmol})$ and $\mathrm{Pd} / \mathrm{C}$ $5 \%(8 \mathrm{mg})$ were mixed in methanol $(2.0 \mathrm{~mL})$. The solution was stirred for $30 \mathrm{~min}$ at reflux temperature $\left(70{ }^{\circ} \mathrm{C}\right)$. The resulting solution was filtrated and the solvent evaporated. A white solid was obtained in $80 \%$ yield $(30 \mathrm{mg}) .{ }^{1} \mathrm{H}$ NMR $\left(400 \mathrm{MHz}, \mathrm{CD}_{3} \mathrm{OD}\right) \mathrm{ppm}$ : 7.68 (dd, $\left.J=7.9,1.5 \mathrm{~Hz}, 1 \mathrm{H}_{\mathrm{Ar}}\right), 7.54\left(\mathrm{~m}, 2 \mathrm{H}_{\mathrm{Ar}}\right), 7.39\left(\mathrm{~m}, 2 \mathrm{H}_{\mathrm{Ar}}\right), 7.27\left(\mathrm{~m}, 2 \mathrm{H}_{\mathrm{Ar}}\right), 7.18\left(\mathrm{~m}, 1 \mathrm{H}_{\mathrm{Ar}}\right), 7.07$ $\left(\mathrm{dd}, J=8.6,2.1 \mathrm{~Hz}, 1 \mathrm{H}_{\mathrm{Ar}}\right), 6.87\left(\mathrm{dd}, J=8.2,1.2 \mathrm{~Hz}, 1 \mathrm{H}_{\mathrm{Ar}}\right), 6.74\left(\mathrm{td}, J=7.6,1.2 \mathrm{~Hz}, 1 \mathrm{H}_{\mathrm{Ar}}\right)$, $3.08\left(\mathrm{~s}, 3 \mathrm{H}_{\mathrm{Me}}\right) ;{ }^{13} \mathrm{C}$ NMR (101 MHz, CD $\left.3 \mathrm{OD}\right)$ ppm: 154.4, 148.9, 148.5, 142.8, 131.6, 131.3, 
128.5, 120.7, 117.9, 117.8, 117.4, 113.5, 113.3, 44.4; HRMS (ESI-TOF) calcd. for $\mathrm{C}_{20} \mathrm{H}_{19} \mathrm{~N}_{4} \mathrm{O}_{2} \mathrm{~S}$ : $[\mathrm{M}+\mathrm{H}]^{+}:$379.1229, found 379.1228 .

\section{Conclusions}

The development of a pharmacophore model of E. coli DNA Gyrase B inhibitors, followed by docking studies using the crystallographic structure of this target, proved to be a relevant tool for the design and synthesis of the new chemical entities, based on 2-(aminophen-2-yl)-5(6)-substituted-1H-benzimidazoles.

The optimization of the condensation/oxidation reaction of 4-bromo-1,2-diaminobenzene with 2-nitrobenzaldehyde, yielding 5(6)-bromo-2-(nitrophen-2-yl)-1H-benzimidazole 1, led us to find a sustainable synthetic approach, using ethanol as solvent and Montmorillonite $\mathrm{K} 10$ as a reusable catalyst, which allowed a significant improvement of product yield and isolation process. Additionally, the $\mathrm{N}$-boc revealed to be the ideal benzimidazole protecting group since its deprotection significantly does not lead to the formation of the side products obtained when using benzyl protecting group.

These studies pave the way for efficient functionalization of the more synthetically challenging 5(6) position, via cross-coupling Suzuki-Miyaura and Buchwald-Hartwig reactions, using multifunctionalized phenylboronic acids (products $8 \mathbf{a}$ and $9 \mathbf{a}$ were isolated with $72 \%$ and $66 \%$, respectively) and amines (3 or 4-(methylsulfonyl)aniline), catalyzed by $\mathrm{Pd} / \mathrm{XPhos}$ (79-81\% isolated yields of 6 and 7). Finally, the use of $\mathrm{NH}_{2} \mathrm{NH}_{2} \cdot \mathrm{H}_{2} \mathrm{O}$ and $\mathrm{Pd} / \mathrm{C}$, under air atmosphere, revealed to be a clean strategy to promote the reduction of the nitro group to the corresponding amine, giving 13,14 , and 15 with $91 \%, 56 \%$, and $80 \%$ yields respectively.

In summary, we have developed efficient synthetic methods to prepare two different families of 2-(2-aminophenyl)-5(6)-substituted-1H-benzimidazoles, which encompass in their structures hydrogen bond donor groups at 2-position, and hydrogen bond acceptor groups at 5(6)- position. According to the predicted docking pose, these groups will favor interactions with Asp73 and Arg136, respectively, and therefore will potentially increase their inhibition potential for E. coli's DNA gyrase B. These new classes of molecules may open new perspectives regarding a broad-range of medicinal applications, particularly for the development of alternative antimicrobial chemical entities effective against $E$. coli. Biological studies are currently underway.

Supplementary Materials: The following are available online. Figure S2: Training set for the development of Escherichia coli's GyrB pharmacophore model; Figure S3: Computational pharmacophore model and docking test/correlation data; Figure S4: Structure of phosphines used; Figures S5-S60: ${ }^{1} \mathrm{H}$ and ${ }^{13} \mathrm{C}$ NMR and HRMS (ESI-TOF) spectra for all synthesized compounds.

Author Contributions: Conceptualization, M.M.P. and R.C.G.; methodology, M.M.P., R.C.G. and R.T.A.; software, R.C.G. and R.T.A.; validation, M.M.P. and R.C.G.; formal analysis, M.M.P., R.C.G. and R.T.A.; investigation, R.T.A.; data curation, R.T.A.; writing-original draft preparation, R.T.A.; writing-review and editing, M.M.P., R.C.G. and R.T.A.; visualization, R.T.A.; supervision, M.M.P. and R.C.G.; project administration, M.M.P. and R.C.G.; funding acquisition, M.M.P. and R.C.G. All authors have read and agreed to the published version of the manuscript.

Funding: The authors acknowledge funding by FCT (Fundação para a Ciência e Tecnologia), QREN/FEDER (COMPETE Programa Operacional Factores de Competitividade) for projects UIDB/ 00313/2020 and PTDC/QUI-OUT/27996/2017 (DUALPI). Rafael T. Aroso thanks FCT for PhD grant $\mathrm{PD} / \mathrm{BD} / 143123 / 2019$.

Institutional Review Board Statement: Not applicable.

Informed Consent Statement: Not applicable.

Data Availability Statement: The data presented in this paper are available in Supplementary Materials.

Acknowledgments: The authors would like to acknowledge University of Coimbra (Coimbra Chemistry Center) and University of Lisbon (iMed.ULisboa) for the facilities provided for research. 
Conflicts of Interest: The authors declare no conflict of interest.

Sample Availability: Samples of the compounds are available from the authors.

\section{References}

1. Vitaku, E.; Smith, D.T.; Njardarson, J.T. Analysis of the structural diversity, substitution patterns, and frequency of nitrogen heterocycles among U.S. FDA approved pharmaceuticals. J. Med. Chem. 2014, 57, 10257-10274. [CrossRef]

2. Luca, L.D. Naturally occurring and synthetic imidazoles: Their chemistry and their biological activities. Curr. Med. Chem. 2006, $13,1-23$.

3. Jakopin, Z.; Ilas, J.; Barancokova, M.; Brvar, M.; Tammela, P.; Sollner Dolenc, M.; Tomasic, T.; Kikelj, D. Discovery of substituted oxadiazoles as a novel scaffold for DNA gyrase inhibitors. Eur. J. Med. Chem. 2017, 130, 171-184. [CrossRef]

4. Gaba, M.; Mohan, C. Development of drugs based on imidazole and benzimidazole bioactive heterocycles: Recent advances and future directions. Med. Chem. Res. 2016, 25, 173-210. [CrossRef]

5. Tahlan, S.; Kumar, S.; Narasimhan, B. Antimicrobial potential of 1h-benzo[d]imidazole scaffold: A review. BMC Chemistry 2019, 13, 18. [CrossRef]

6. Cho, J.C.; Crotty, M.P.; Pardo, J. Ridinilazole: A novel antimicrobial for clostridium difficile infection. Ann. Gastroenterol. 2019, 32, 134-140. [CrossRef]

7. World Health Organization. Global Priority List of Antibiotic Resistant Bacteria to Guide Research, Discovery, and Development of New Antibiotics; World Health Organization: Geneva, Switzerland, 2017; pp. 1-7.

8. Saíz-Urra, L.; Pérez, M.Á.C.; Froeyen, M. Thermodynamic computational approach to capture molecular recognition in the binding of different inhibitors to the DNA gyrase b subunit from escherichia coli. J. Mol. Model. 2013, 19, 3187-3200. [CrossRef]

9. Tomašič, T.; Barančoková, M.; Zidar, N.; Ilaš, J.; Tammela, P.; Kikelj, D. Design, synthesis, and biological evaluation of 1-ethyl-3(thiazol-2-yl)urea derivatives as escherichia coli DNA gyrase inhibitors. Arch. Pharm. 2018, 351, 1700333-n/a. [CrossRef]

10. Gjorgjieva, M.; Tomašič, T.; Barančokova, M.; Katsamakas, S.; Ilaš, J.; Tammela, P.; Peterlin Mašič, L.; Kikelj, D. Discovery of benzothiazole scaffold-based DNA gyrase b inhibitors. J. Med. Chem. 2016, 59, 8941-8954. [CrossRef]

11. Chemical Computing Group ULC. Molecular Operating Environment (MOE). Available online: https:/ /www.chemcomp.com/ Products.htm (accessed on 7 January 2021).

12. Alaqeel, S.I. Synthetic approaches to benzimidazoles from o-phenylenediamine: A literature review. J. Saudi Chem. Soc. 2017, 21, 229-237. [CrossRef]

13. Sreerama, R.; Barnali, M.; Balamurali, M.M.; Kaushik, C. Synthesis and medicinal applications of benzimidazoles: An overview. Curr. Org. Synth. 2017, 14, 40-60.

14. Jyoti, S.; Pradeep, K.S.; Ravi, B.; Anand, K.H. Synthetic approaches towards benzimidazoles by the reaction of o-phenylenediamine with aldehydes using a variety of catalysts: A review. Curr. Org. Chem. 2018, 22, 2280-2299.

15. Faheem, M.; Rathaur, A.; Pandey, A.; Kumar Singh, V.; Tiwari, A.K. A review on the modern synthetic approach of benzimidazole candidate. ChemistrySelect 2020, 5, 3981-3994. [CrossRef]

16. Zheng, Y.; Zheng, M.; Ling, X.; Liu, Y.; Xue, Y.; An, L.; Gu, N.; Jin, M. Design, synthesis, quantum chemical studies and biological activity evaluation of pyrazole-benzimidazole derivatives as potent aurora a/b kinase inhibitors. Bioorg. Med. Chem. Lett. 2013, 23, 3523-3530. [CrossRef]

17. Starčević, K.; Kralj, M.; Ester, K.; Sabol, I.; Grce, M.; Pavelić, K.; Karminski-Zamola, G. Synthesis, antiviral and antitumor activity of 2-substituted-5-amidino-benzimidazoles. Biorg. Med. Chem. 2007, 15, 4419-4426. [CrossRef]

18. Joy, M.; Karuvalam, R.; Haridas, K.; Sajith, A.; Pakkath, R.; Bhaskaran, S.; Padusha, M.; Bakulev, V. Suzuki-miyaura coupling under microwave enhanced conditions: Synthesis of 2-(hetero)aryl benzimidazoles. Arkivoc 2020, 2019, 431-445.

19. Ezquerra, J.; Lamas, C.; Pastor, A.; García-Navío, J.; Vaquero, J.J. Suzuki-type cross-coupling reaction of 1-benzyl-2-iodo-1hbenzimidazoles with aryl boronic acids: A regioselective route to n-alkylated 6-alkoxy-2-aryl-1h-benzimidazoles. Tetrahedron 1997, 53, 12755-12764. [CrossRef]

20. Düfert, M.A.; Billingsley, K.L.; Buchwald, S.L. Suzuki-miyaura cross-coupling of unprotected, nitrogen-rich heterocycles: Substrate scope and mechanistic investigation. J. Am. Chem. Soc. 2013, 135, 12877-12885. [CrossRef]

21. Martin, A.D.; Siamaki, A.R.; Belecki, K.; Gupton, B.F. A convergent approach to the total synthesis of telmisartan via a suzuki cross-coupling reaction between two functionalized benzimidazoles. J. Org. Chem. 2015, 80, 1915-1919. [CrossRef]

22. Savall, B.M.; Fontimayor, J.R. Synthesis of 2-arylbenzimidazoles via microwave suzuki-miyaura reaction of unprotected 2chlorobenzimidazoles. Tetrahedron Lett. 2008, 49, 6667-6669. [CrossRef]

23. Hooper, M.W.; Utsunomiya, M.; Hartwig, J.F. Scope and mechanism of palladium-catalyzed amination of five-membered heterocyclic halides. J. Org. Chem. 2003, 68, 2861-2873. [CrossRef] [PubMed]

24. Kawasaki, I.; Taguchi, N.; Yoneda, Y.; Yamashita, M.; Ohta, S. Highly effective procedure for introduction of amino group into the 2-position of imidazole ring. Heterocycles 1996, 43, 1375-1379. [CrossRef]

25. Coon, T.; Moree, W.J.; Li, B.; Yu, J.; Zamani-Kord, S.; Malany, S.; Santos, M.A.; Hernandez, L.M.; Petroski, R.E.; Sun, A.; et al. Brain-penetrating 2-aminobenzimidazole h1-antihistamines for the treatment of insomnia. Bioorg. Med. Chem. Lett. 2009, 19, 4380-4384. [CrossRef] [PubMed] 
26. Sang, W.; Gavi, A.J.; Yu, B.-Y.; Cheng, H.; Yuan, Y.; Wu, Y.; Lommens, P.; Chen, C.; Verpoort, F. Palladium-catalyzed ligand-free c-n coupling reactions: Selective diheteroarylation of amines with 2-halobenzimidazoles. Chem. Asian J. 2020, 15, 129-135. [CrossRef] [PubMed]

27. Gergely, M.; Bényei, A.; Kollár, L. 2-aminobenzimidazole and -benzoxazole as n-nucleophile in palladium-catalysed aminocarbonylation. Tetrahedron 2020, 76, 131079. [CrossRef]

28. Cheung, M.; Emmitte, K.A.; Salovich, J.M. Benzimidazole Thiophene Compounds as PLK Inhibitors. Patent No. WO2007/030361A2, 15 March 2007.

29. Jain, P.; Yi, S.; Flaherty, P.T. Suzuki-miyaura cross-coupling of potassium organoborates with 6-sulfonate benzimidazoles using microwave irradiation. J. Heterocycl. Chem. 2013, 50, E166-E173. [CrossRef]

30. Kasai, S.; Igawa, H.; Takahashi, M.; Maekawa, T.; Kakegawa, K.; Yasuma, T.; Kina, A.; Aida, J.; Khamrai, U.; Kundu, M. Benzimidazole Derivatives as MCH Receptor Antagonists. Patent No. WO/2013/105676, 18 July 2013.

31. Chang, S.-Y.; Lin, G.-T.; Cheng, Y.-C.; Huang, J.-J.; Chang, C.-L.; Lin, C.-F.; Lee, J.-H.; Chiu, T.-L.; Leung, M.-K. Construction of highly efficient carbazol-9-yl-substituted benzimidazole bipolar hosts for blue phosphorescent light-emitting diodes: Isomer and device performance relationships. ACS Appl. Mater. Interfaces 2018, 10, 42723-42732. [CrossRef]

32. López-Rodríguez, M.a.L.; Benhamú, B.; Ayala, D.; Rominguera, J.L.; Murcia, M.; Ramos, J.A.; Viso, A. Pd(0) amination of benzimidazoles as an efficient method towards new (benzimidazolyl)piperazines with high affinity for the 5-ht1a receptor. Tetrahedron 2000, 56, 3245-3253. [CrossRef]

33. Boydston, A.J.; Vu, P.D.; Dykhno, O.L.; Chang, V.; Wyatt, A.R.; Stockett, A.S.; Ritschdorff, E.T.; Shear, J.B.; Bielawski, C.W. Modular fluorescent benzobis(imidazolium) salts: Syntheses, photophysical analyses, and applications. J. Am. Chem. Soc. 2008, 130, 3143-3156. [CrossRef]

34. Chen, Y.-C.; Faver, J.C.; Ku, A.F.; Miklossy, G.; Riehle, K.; Bohren, K.M.; Ucisik, M.N.; Matzuk, M.M.; Yu, Z.; Simmons, N. C-n coupling of DNA-conjugated (hetero)aryl bromides and chlorides for DNA-encoded chemical library synthesis. Bioconjugate Chem. 2020, 31, 770-780. [CrossRef]

35. Durcik, M.; Tammela, P.; Barančoková, M.; Tomašič, T.; Ilaš, J.; Kikelj, D.; Zidar, N. Synthesis and evaluation of nphenylpyrrolamides as DNA gyrase b inhibitors. ChemMedChem 2018, 13, 186-198. [CrossRef]

36. Ostrov, D.A.; Hernández Prada, J.A.; Corsino, P.E.; Finton, K.A.; Le, N.; Rowe, T.C. Discovery of novel DNA gyrase inhibitors by high-throughput virtual screening. Antimicrob. Agents Chemother. 2007, 51, 3688-3698. [CrossRef] [PubMed]

37. Eakin, A.E.; Green, O.; Hales, N.; Walkup, G.K.; Bist, S.; Singh, A.; Mullen, G.; Bryant, J.; Embrey, K.; Gao, N.; et al. Pyrrolamide DNA gyrase inhibitors: Fragment-based nuclear magnetic resonance screening to identify antibacterial agents. Antimicrob. Agents Chemother. 2012, 56, 1240-1246. [CrossRef] [PubMed]

38. Cotman, A.E.; Trampuž, M.; Brvar, M.; Kikelj, D.; Ilaš, J.; Peterlin-Mašič, L.; Montalvão, S.; Tammela, P.; Frlan, R. Design, synthesis, and evaluation of novel tyrosine-based DNA gyrase b inhibitors. Archiv Pharmazie 2017, 350, 1700087-n/a. [CrossRef]

39. Basarab, G.S.; Manchester, J.I.; Bist, S.; Boriack-Sjodin, P.A.; Dangel, B.; Illingworth, R.; Sherer, B.A.; Sriram, S.; Uria-Nickelsen, M.; Eakin, A.E. Fragment-to-hit-to-lead discovery of a novel pyridylurea scaffold of atp competitive dual targeting type ii topoisomerase inhibiting antibacterial agents. J. Med. Chem. 2013, 56, 8712-8735. [CrossRef]

40. Ronkin, S.M.; Badia, M.; Bellon, S.; Grillot, A.-L.; Gross, C.H.; Grossman, T.H.; Mani, N.; Parsons, J.D.; Stamos, D.; Trudeau, M.; et al. Discovery of pyrazolthiazoles as novel and potent inhibitors of bacterial gyrase. Bioorg. Med. Chem. Lett. 2010, 20, 2828-2831. [CrossRef]

41. Trzoss, M.; Bensen, D.C.; Li, X.; Chen, Z.; Lam, T.; Zhang, J.; Creighton, C.J.; Cunningham, M.L.; Kwan, B.; Stidham, M.; et al. Pyrrolopyrimidine inhibitors of DNA gyrase b (gyrb) and topoisomerase iv (pare), part ii: Development of inhibitors with broad spectrum, gram-negative antibacterial activity. Bioorg. Med. Chem. Lett. 2013, 23, 1537-1543. [CrossRef] [PubMed]

42. Tari, L.W.; Li, X.; Trzoss, M.; Bensen, D.C.; Chen, Z.; Lam, T.; Zhang, J.; Lee, S.J.; Hough, G.; Phillipson, D.; et al. Tricyclic gyrb/pare (tribe) inhibitors: A new class of broad-spectrum dual-targeting antibacterial agents. PLoS ONE 2013, 8, e84409. [CrossRef]

43. Jones, G.; Willett, P.; Glen, R.C.; Leach, A.R.; Taylor, R. Development and validation of a genetic algorithm for flexible docking. J. Mol. Biol. 1997, 267, 727-748. [CrossRef]

44. Mann, J.; Baron, A.; Opoku-Boahen, Y.; Johansson, E.; Parkinson, G.; Kelland, L.R.; Neidle, S. A new class of symmetric bisbenzimidazole-based DNA minor groove-binding agents showing antitumor activity. J. Med. Chem. 2001, 44, 138-144. [CrossRef]

45. Pessoa-Mahana, D.; Espinosa-Bustos, C.; Mella-Raipán, J.; Canales-Pacheco, J.; Pessoa-Mahana, H. Microwave-assisted synthesis and regioisomeric structural elucidation of novel benzimidazo[1,2d][1,4]benzodiazepinone derivatives. Arkivoc 2009, 7, 131-140. [CrossRef]

46. Yadagiri, B.; Lown, J.W. Convenient routes to substituted benzimidazoles and imidazolo[4,5-b]pyridines using nitrobenzene as oxidant. Synth. Commun. 1990, 20, 955-963. [CrossRef]

47. Miyaura, N.; Suzuki, A. Palladium-catalyzed cross-coupling reactions of organoboron compounds. Chem. Rev. 1995, 95, 2457-2483. [CrossRef]

48. Fernández, F.; Cordero, B.; Durand, J.; Muller, G.; Malbosc, F.; Kihn, Y.; Teuma, E.; Gómez, M. Palladium catalyzed suzuki c-c couplings in an ionic liquid: Nanoparticles responsible for the catalytic activity. Dalton Trans. 2007, 5572-5581. [CrossRef] [PubMed] 
49. Hooshmand, S.E.; Heidari, B.; Sedghi, R.; Varma, R.S. Recent advances in the suzuki-miyaura cross-coupling reaction using efficient catalysts in eco-friendly media. Green Chem. 2019, 21, 381-405. [CrossRef]

50. Ruiz-Castillo, P.; Buchwald, S.L. Applications of palladium-catalyzed c-n cross-coupling reactions. Chem. Rev. 2016, 116, 12564-12649. [CrossRef] [PubMed]

51. Surry, D.S.; Buchwald, S.L. Dialkylbiaryl phosphines in pd-catalyzed amination: A user's guide. Chem. Sci. 2011, 2, 27-50. [CrossRef]

52. King, A.O.; Larsen, R.D.; Negishi, E. Palladium-catalyzed heterogeneous hydrogenation. In Handbook of Organopalladium Chemistry for Organic Synthesis; Negishi, E., Ed.; Wiley: New York, NY, USA, 2002; pp. 2719-2752.

53. Greene, T.W.; Wuts, P.G.M. Protection for the amino group (3rd edition). In Protective Groups in Organic Synthesis; John Wiley \& Sons, Inc.: New York, NY, USA, 1999; pp. 494-653. 